THE UNIVERSITY OF MANITOBA

EVALUATION OF A PRECIPITATION HARDENED WROUGHT COBALT-NICKEL-CHROMIUM-TITANIUM ALLOY FOR SURGICAL IMPLANTS

By

Liliane (Dubois) HILL

\begin{abstract}
A THESIS
SUBMITTED TO THE FACULTY OF GRADUATE STUDIES

IN PARTIAL FULFILMENT OF THE REQUIREMENTS FOR THE DEGREE OF MASTER OF SCIENCE
\end{abstract}

DEPARTMENT OF MECHANICAL ENGINEERING

WINNIPEG, MANITOBA

MAY 1978

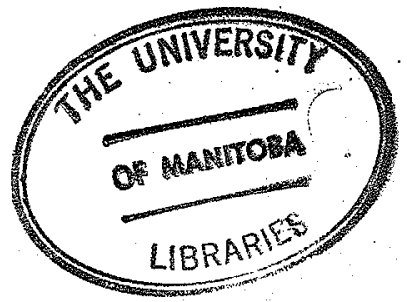




\section{EVALUATION OF A PRECIPITATION HARDENED WROUGHT}

COBALT-NICKEL-CHROMIUM-TITANIUM ALLOY FOR SURGICAL IMPLANTS

BY

LILIANE (DUBOIS) HILL

A dissertation submitted to the Faculty of Graduate Studies of the University of Manitoba in partial fulfillment of the requirements of the degree of

MASTER OF SCIENCE

(c) 1978

Permission has been granted to the LIBRARY OF THL UNIVERSITY OF MANITOBA to lend or sell copies of this dissertation, to the NATIONAL LIBRARY OF CANADA to microfilm this dissertation and to lend or sell copies of the film, and UNIVERSITY MICROFILMS to publish an abstract of this dissertation.

The author reserves other publication rights, and neither the dissertation nor extensive extracts from it may be printed or otherwise reproduced without the author's written permission. 


\section{ACKNOWLEDGMENTS}

The author wishes to thank Sherritt Gordon Mines Limited and the International Nickel Company of Canada Limited, who supplied cobalt and nickel for preparation of the alloys. The author is also grateful for financial support supplied by the Medical Research Council of Canada, the National Research Council of Canada and the Graduate Research Board of the University of Manitoba. The experimental assistance of Dr. F. Gunston of the Faculty of Medicine, University of Manitoba, who implanted the specimens and Dr. J. Hoogstraten of the Health Sciences Centre, Winnipeg, who performed the pathological studies is greatly appreciated. A special thanks to Dr. J. R. Cahoon, Department of Mechanical Engineering, who supervised my thesis, Mrs. R. Hanley for the typing, and Mr. H. Weiss of Central Drafting Service for the figures. 


\section{TABLE OF CONTENTS}

Page

ACKNOWLEDGEMENTS ....................

LIST OF FIGURES .......................... $i$

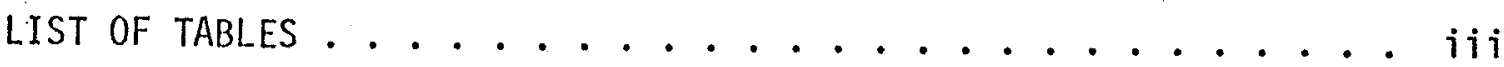

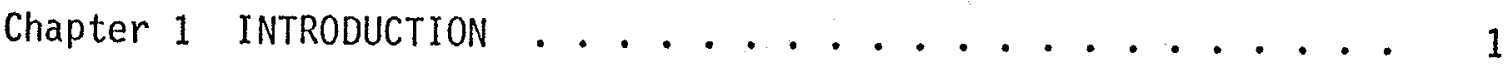

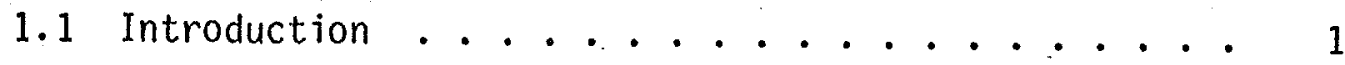

Chapter 2 REVIEW OF THE LITERATURE ............. 3

2.1 Implants and Their Problems (Abstract) ...... 3

2.2 Literature Review.............. 3

2.3 Conclusion .................. 15

Chapter 3 EXPERIMENTAL TECHNIQUES .............. 17

3.1 Alloy Preparation . . . . . . . . . . 17

3.2 Static Strength . . . . . . . . . . . 17

3.3 Fatigue Strength ............ . . 17

3.4 In-Vitro Corrosion Testing ......... 19

3.5 In-Vivo Corrosion Testing .......... 23

Chapter 4 RESULTS ..................... 25

Chapter 5 DISCUSSION ........................... 44

Chapter 6 CONCLUSIONS . . . . . . . . . . . . . 49

REFERENCES ....................... 50 


\section{LIST OF FIGURES}

Figure

Page

1 Schematic Circuitry for Potentiodynamic Polarization . . . 24

2 Fatigue Strength of Co-Ni-Cr-Ti Alloy ....... 26

3 Cathodic Polarization Results for Co-Ni-Cr-Ti Alloy . . . 28

4 Linear Anodic Polarization Results for Co-Ni-Cr-Ti Alloy . . 31

5 Cyclical Potentiodynamic Scan for Co-Ni-Cr-Ti Alloy (Test \#1) 32

6

7

8

9

10

11

12

13
"1

11

1

II

11

II

II

"
$\|$

11

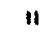

\section{II}

11

II.

II

II it. 11

II

111

"

11

II

11

II
11

11

II

11

iI

n

"

"1
1 (Test \#2) 33

" (Test \#3) 34

" (Test \#4) 35

" (Test \#5) 36

" (Test \#6) 37

" (Test \#7) 38

" (Test \#8) 39

" (Test \#9) 40 
iii.

\section{LIST OF TABLES}

Table

Page

I Composition of Metallic Surgical Implant Materials . . . 16

II Nominal Composition and Material Purity for $\mathrm{CO}-\mathrm{Ni}-\mathrm{Cr}-\mathrm{Ti} \mathrm{Allloy}$. . . . . . . . . . . . . 18

II Compositions of Ringer's Solution and Extracellular Fluid . 20

IV $\mathrm{O}_{2}$ and $\mathrm{CO}_{2}$ Concentrations for In-Vitro Corrosion Tests . . . 22

$\checkmark$ Tensile Properties of Co-Ni-Cr-Ti Alloy . . . . . . . 22

VI Fatigue Life of CO-Ni-Cr-Ti Alloy at Stress Ratio R $=0$. . 27

VII Fatigue Life of $\mathrm{CO}-\mathrm{Ni}-\mathrm{Cr}-\mathrm{Ti}$ Alloy at Stress Ratio $\mathrm{R}=-1$. . 27

VIII Cathodic and Linear Polarization Results for $\mathrm{CO}-\mathrm{Ni}-\mathrm{Cr}-\mathrm{Ti}-\mathrm{Alll}$. . . . . . . . . . . 29

IX Summary of Cyclic Anodic Polarization Results on Co-Ni-Cr-Ti Alloy . . . . . . . . . . . 42

X Results of. In-Vivo Corrosion Studies on CO-Ni-Cr-Ti Alloy . 43 


\section{CHAPTER 1}

\section{INTRODUCTION}

\subsection{Introduction}

Orthopedic surgery is a science which is in a perpetual state of development. The instruments necessary to assist the surgeon in his task are always subject to study and improvement. One of the main instruments is the surgical implant.

The challenge encountered in the search for the ideal surgical implant is caused by the conditions under which it must perform. An ideal implant should meet the following requirements:

1. have sufficient static and fatigue strength and wear resistance for thè application

2. be non toxic, non allergenic and non carcinogenic 3. be non corrosive in the physiological environment 4. have no effect on the host tissue, bone or body fluids.

A chapter of this thesis is reserved for the study in chronological order from the $1930^{\prime} s$ to the present, of the research and experimentations which have led to today's prosthesis and outlines the problems which still remain to be solved because of what is asked of a surgical implant.

The stringent requirements for implant alloys severely restricts the types of alloys which might be used. For the most part, pure metals or single phase alloys have been selected because these materials generally exhibit superior corrosion resistance. However, restricting implant alloys 
to pure or single phase materials limits the strength of the material in that the only strengthening mechanisms which can be utilized are solid solution strengthening, cold working, and grain size control. The use of precipitation hardening alloys for surgical implants offers the potential for obtaining higher strength materials but their use has been avoided probably because of a fear of poor corrosion resistance and resultant deleterious effects on the body environment.

The development of a precipitation hardening superalloy [8] containing $40 \% \mathrm{Co}, 37 \% \mathrm{Ni}, 18 \% \mathrm{Cr}, 5 \% \mathrm{Ti}$, all elements which have proved acceptable for surgical implants, suggests that this alloy may be suitable for implant applications. A study of this alloy was therefore conducted to evaluate its potential for use as an implant alloy. The parameters investigated were:

1. Static strength

2. Fatigue strength

3. In-vitro corrosion resistance

4. In-vivo corrosion resistance. 
CHAPTER 2

REVIEW OF THE LITERATURE

\subsection{Implants and Their Problems}

Abstract

Orthopedic surgery has been performed for hundreds of years, and was of great interest in the 19th century. But it was not until the years 1940 - 1950, the "war and post war years", that concern and improvement appeared in the design and choice of materials for implant purposes. The following is a survey, in chronological order, of the successes, failures, and problems created by implants and subsequent improvements that led to today's orthopedic devices and surgical techniques.

\subsection{Literature Review}

Implants were first used to repair broken bones, and in 1930 the first internal prostheses, made of mild steel, were tested with fairly good results, but corrosion was often reported.

In the year 1950, the use of implants was more widespread, and metallic devices were sometimes used for different purposes, one of . those purposes being femoral lengthening [20]. The latest gave very few encouraging results, and when failure occurred, no mention was made of the possibility of an implant failure.

In 1951, the implants, then called internal fixation or internal prosthesis, seemed to give fairly encouraging results, even if the breaking 
of some of those devices [21] was often reported. Still very little was said about the standard requirements of those devices.

In 1952, rapid improvements were made in hip joint surgery, especially when a new device appeared as a surgical implant. This new implant, the "door knob prosthesis" [22] was screwed into the medullary canal and was reported to be made of either vitallium or stainless steel, type 317. Its inventor, Dr. McBride, described it as a hip joint prosthesis composed of a spherical head, a neck, and a threaded intramedullary stem.

For this implant material, Dr. McBride chose either stainless steel type 317 , or vitallium. The reason for his choice was that the above were "dependably non-electrolytic", in other words, corrosion resistant.

As the use of metallic implants was growing, so grew the concern for the "non-electrolytic" quality of the materials used. Of all the studies, one of the most remarkable, for its concern of the metallurgical problems involved, was that of Dr. P. G. Laing on the corrosion resistance of the orthopedic implant [23]. In this article, it was said that: "Certain metals and alloys with suitable strength for orthopedic purposes are more resistant to corrosion than others under the special conditions existing in the human body. Of these, stainless steel, known as AISI \#316, and the cobalt, chromium, molybdenum alloy known as vitallium are in common use." In the same article, factors encouraging corrosion in the body were equally listed, mainly mixed metals, fretting corrosion, 
differential aeration. Experiments were made on rabbits, and the corrosion of orthopedic screws was measured by weighing before and after insertion in the animal, and by doing histological studies of tissues around the implants. It was concluded that the metallic transfer from screwdriver to screw appeared to adversely influence the corrosion resistance of the screw and the composition of the driver would have to be related to that of the screw.

During the same period, in England, Dr. J. Cohen was working on foreign body reactions. His method consisted in metal powder injection inside living organisms. The result of his work showed that only a few metals and plastics were inert, the inertness being relative, because in the form of fine powders, even those materials considered least provocative of inflammation would cause appreciable tissue reaction. The conclusion of his work showed that the least corrosion was reported when a powder alloy made of chromiun and cobalt was used. It also showed. that mild steel gave very violent tissue reactions.

Dr. J. Cohen pointed out the danger of corrosion products in a human organism, when he reported in another article [24] a case of fracture by corrosion of a Smith Peterson nail - Thornton plate, made of stainless steel, which caused the death due to necrosis of an elderly lady; infection, and a massive heart failure, a pattern unfortunately too well known today with elderly patients suffering from implant failures.

Meanwhile, Dr. Laing completed a study [25] in applied metallurgy on the contamination of implants. His conclusions were that the 2 factors 
involved in the process of contamination. were:

1) Metallic transfer.

2) Flaking of large pieces of the tip of the screwdriver by the cutting action of the screw siot against the screwdriver.

At the beginning of the $1960^{\prime} s$, Dr. Ferguson and Dr. Laing reported experimental evidence that ionization occurs around al1 types of metallic alloys currently in use in human bodies, regardless of how resistant to corrosion these alloys are thought to be [26].

Meanwhile, Dr. Cohen reported on another case of failure by corrosion [27], this time from a Steinmann pin used for intramedullary fixation. It was established that the cause was the choice of dissimilar steels for screws and pins, the screws being made of AISI type 316 stainless steel and the pin of a type 420. It was determined that the composition of the steel was the principal fact in promoting corrosion, although cyclic stresses and non-metallic inclusions probably influenced the localization of the corrosion process.

By 1960 - 1962, already 30 years had passed since the first orthopedic devices had been implanted, so the first long range studies of implant behavior were now possible. In one of the studies [28] the tendency of implants to provoke wound reactions was analyzed. In this particular study, the cobalt-chromium alloy proved to be the better, the incidence of obligatory removal being at most $3 \%$, while the $18 / 8$ molybdenum stainless steel proved to be the poorest, with an incidence of $20 \%$. 
In March 1962, Dr. J. Cohen tested the corrosion resistance of vitallium and AISI type 316 stainless steel under condition of cyclic stress, in vitro. Vitallium showed the greatest corrosion resistance under those experimental conditions [29].

Meanwhile, Dr. Laing and Dr. Ferguson started a study of the trace metal ion concentration in the liver, kidney, spleen, and lung of the normal rabbit. This study of normal trace ion concentration for 4 major organs in the rabbit was done to provide a baseline against which a rise in concentration of ions could be determined when the experiments were varied. During the same month, they published another study of ion concentation for 4 major organs, but this time with imbedded metal implants in rabbits [30]. The results of this study showed that stainless steel contributed nickel to the body circulation, and cobalt based elements contributed cobalt. The spleen was found to be the most active site of trace iron storage - the other organs, especially the liver, tending to get rid of an early increase in concentration. Cobalt and nickel were the most active ions in terms of their presence in these organs.

In 1964, a study and survey of 455 patients was made on the use and justification of acrylic cement in the bonding of prosthesis [31]. It was reported that no sign of deterioration of the bond between the cement and bone had been seen in histological preparation up to three and a quarter years after the operation, and no harmful effect had been recognized or suspected in the patients in whom it had been used. The technique was considered justifiable in elderly patients when the medullary canal is large and the cortex of the femur is thin and brittle. 
of course, as problems in orthopedic surgery increased, some standards for implant materials had to be defined [32] and the validity of the whole process had to be discussed [33]. The F4 (Surgical Material) Committee of the ASTM held a meeting in Cleveland (Ohio) on April 20, 1967, to develop specifications for materials to be used in surgical implants and to develop procedures with regard to testing and handling the like. In the same meeting, in reply to $\mathrm{Dr}$. A. Dawkins who had seen in Russia massive replacement by cadaveric bones, it was said that metal replacement promised a better and quicker result.

In the middle 1960's not every problem encountered in orthopedic surgery was solved [34]. For example, the management of advanced degenerative arthritis of the hip, especially when bilateral, remained unsolved. But the vitallium cup arthroplasty pioneered by Smith-Peterson in 1939 had been refined and its indications, scope and results well documented [35].

Medullary stem prosthesis of vitallium had proved satisfactory and of these the Austin-Moore and Thompson design were the ones most commonly used for degenerative arthritis. This method showed a variable degree of improvement in all patients. There was a worthwhile improvement in functions and relief of pain, but stability was disappointing in more than half the cases (and in all the bilateral cases) and an average of $3 / 4$ of an inch of shortening was found in the unilateral cases. The conclusion was that the use of the Austin-Moore prosthesis with acetabular reaming had very limited indications.

In the same month, an article appeared on the replacement of arthritic hips by the McKee-Farrar prosthesis. It was noted that "it 
seemed obvious that the chromium-cobalt alloy had decided advantages over stainless steel." The joint consisted of two components; the femoral, which was a standard Thompson prosthesis, and the acetabular reaming which was a hemispherical cup lapped in to fit the head of the Thompson prosthesis. The results were encouraging, showing a success rate of $90 \%$.

In 1966, there appeared an article that showed concern about the effect of metal implants inside the human body [36]. The author stated that "the liberation into tissues of the product of corrosion of various pure metals and of alloys used for surgical implants has been shown by spectrochemical analysis [37], and the presence of those products has been thought to explain:

1) the persistence of infections in the presence of surgical implants

2) the occurrence of an apparently sterile inflammatory response to metallic implants

3) persistent pain in relation to an implant."

In summary, this study shows that the corrosion of an $18 \% \mathrm{Cr}$, $8 \% \mathrm{Ni}, 3 \%$ Mo stainless steel implant, and of some pure metals, may affect not only the surrounding tissues but also the individual cell. Also metallic contamination from surgical tools was confirmed.

Later, the toxicity of metal particles of several corrosion resistant alloys, mainly stainless steel and cobalt chromium alloy [38] was investigated by exposing tissue cultures to powders of these alloys 
and counting the cell population after standard replication intervals. The difference in the degree of toxicity of these alloys, not demonstrated by "in vivo" method was elicited. But in Part II of the same paper [39] the same procedure was repeated with a significant difference, the counting of cells now being made in the lag phase rather than in the replica phase. Several metals used in orthopedic surgery and known to be well tolerated in tissues, clinically were shown to have significant toxicity for tissue culture cells, the cobalt-chromium alloy being more toxic than the stainless steel of type 316. Tissue culture cells containing materials derived from the alloy (corrosion products) were observed in mitosis and cells so labelled survived as many às 15 sequences of subculture.

These results seemed to be confirmed when in 1968, during a study on a vitallium-hinge artheoplasty performed according to the method described by Young, the inertness of vitallium is questioned [40]. Clinically the patient had no complication or chemical evidence of tissue reaction, but pathologically a massive amount of prussian blue positive staining material was found in the capsule and lining the canal formed by the stem of the prosthesis. Mechanical wear or corrosion was evident at the area of contact and on the central axis of the hinge. But still difficult operations are performed with the help of metallic implants, like in the case of a massive osteolysis (vanishing bone disease) of the humerus treated by resection and prosthetic replacement by Dr. H. Poirier. In this particular case the diseased bone was resected leaving only the lower part of the humerus, and replaced with success by a titanium prosthesis. 
At the same time, Dr. Homsy presented a study on corrosion of SMO stainless steel fracture fixation plate showing them to be susceptible to crevice corrosion. It was shown that the introduction of a polymeric stress membrane helped to lessen the incidence of interaction between the screw and the plate without altering the stability of the fixation device. Two years later, in another study, Dr. Charles and Dr. Homsy noticed that there was a tendency of apposed tissues and bones to become tightly adhered to the implant and that these adhesions complicated removal of symptomatic appliances [41]. On this basis, surface roughness and surface energy were reduced by filling surface pores with teflon TFE which seemed to reduce the tendency for intimate adhesion of the cellular environment of the iniplant. During the same year (1968) J. R. Cahoon and H. W. Paxton published in the Journal of Biomedical Materials Research a study on metallurgical analyses of failed orthopedic implants [2] which showed that fatigue was one of the major sources of failure and that fatigue was a result of poor design or poor material, and stressed the importance of an efficient control of fabrication at the manufacturing level to insure that the A.S.T.M. specifications control metal content and porosity of implants.

In February 1970, on a study made in Vietnam, the use of metallic internal fixation in the primary treatment of 176 open skeletal injuries was discussed and the results demonstrated that the use of stainless steel in this type of injury had no harmful effect. It can be used with safety and benefit in the primary treatment of open skeletal wounds especially in the multiple and complicated injuries of war and motor vehicle accidents. 
The same year, J. R. Cahoon and H. W. Paxton published a metallurgical survey of current orthopedic implants [17] showing over $50 \%$ of the sampled current orthopedic implants contained metallurgical or design deficiencies similar to the ones which have been known to cause failure. It was suggested that rigorous inspection procedures at the manufacturing level be established to insure that defective implants are not marketed. In 1971, a fiber titanium composite was developed [42] and its potential application as a method of skeletal fixation for internal prosthetic devices had been studied and found quite satisfactory, as it would provide fixation to bone and uniform stress distribution at the implant bone interface.

By June 1971, an orthopedic technique, the closed intermedullary nailing of the femur method, promoted by Dr. K. Clawson, was considered safe for treating nost femoral-shaft fractures and for obtaining early functional recovery, no infections ar non-unions were reported. During the same period, the technique of artheography, that is, the technique of total hip replacement was widely accepted. The devices used for this purpose were either of the type McKee-Farrar with vitallium to vitallium bearing, or of the Charmley's one (high density polyethylene to stainless steel bearing). Patients with persistent pains after total hip replacement of the hip were reported, but the cause was not clearly defined as very few loosenings of the prosthesis were reported.

In February 1972, the metal failure of a Kuntsher nail, reported by Dr. Critchley, created new problems. The nail was made of 18/8 SMO steel and the analysis showed it to be low in molybdenum and to have more 
non-metallic inclusions than control implants. The importance of protecting the highly polished surface of all metal implants during autoclaving, handling and insertion was stressed.

In February 1973, an article was published on Smith's fracture and $i$ ts reduction by the Ellis plate [43]. In the three types of Smith's fracture, internal fixation was considered.

Type 1 was treated equally well with plastic or internal fixation. The only indication for open reduction and fixation with the Ellis plate was persistent anterior angulation at the fracture site despite the external splintage. Type 2 was treated by open reduction and fixation with the Ellis plate. The Ellis plate was not indicated for the routine treatment of type 3 fracture.

The study and testing of former implant techniques and material was performed in 1973. In March 1973, a preliminary report of 150 cases on the treatment of femoral fractures by internal fixation that showed encouraging results [44] was published. It was said that this technique improved the results by providing stable fixation and more rapid and complete revascularization of the femoral head made eschemic by the fracture.

In April 1973, a study made on the long term results of femoral head replacement [45] showed that in a study of 436 cases of replacement of the femoral head by Austin-Moore, Thompson, Vales and Judet, prosthes is done from 1950 to 1965 revealed best results with the Austin-Moore prosthesis. The Austin-Moore prosthesis performance was rated as follows: 


$$
\begin{aligned}
31 \% & \text { - excellent } \\
36 \% & - \text { good } \\
25 \% & \text { - fair } \\
8 \% & \text { - poor }
\end{aligned}
$$

Relatively few patients showed much change in the results obtained; roughly as many showed long term improvement as showed deterioration. During the same year, A. Weinstein et al. [3] published a paper in the Journal of Biomedical Materials Research Symposium on the clinical and metallurgical analysis of orthopedic implants. The study showed that the most significant reasons for removal were infection, corrosion and fatigue failure. The recommendation of the study was that every effort to optimize the design and materials of implants be made. The importance of quality control and the necessity for having metallurgical data made available to the medical profession to determine an implant performance was also stressed.

In 1974, $\dot{N}$. Semlitsch published a paper in Engineering in Medicine [19] on technical progress in artificial hip joints which summarized the development of material for artificial hip joints from 1939 to 1973 and introduced the aluminium oxide ceramic material, used for the first time in 1970, and unequalled for its high resistance to abrasion. However, long term clinical results must be accumulated before the performance of this material may be properly assessed. 
15.

\subsection{Conclusion}

Today most surgical implants are made from type 316 stainless steel, cobalt-chromium-molybdenum alloy, and titanium (Table I). Although the results obtained from these materials are generally adequate, there remains a low but persistent incidence of failure [7]. The term "failure" may be applied equally to mechanical failure or to an implant which must be removed from a patient because corrosion products can no longer be tolerated. Potentio-methods in in vivo studies were carried out, with titanium and cobalt-chromium-nickel alloys giving the best results.

The conclusion is that detailed metallurgical and corrosion studies cannot always be relied upon to provide a full account of a particular failure. Knowledge must be taken of the clinical and manufacturing details to improve implant performances. It is, therefore, essential that the fullest cooperation is maintained between surgeons, manufacturers, and specialists in materials. 
TABLE I

Composition of Metallic Surgical Implant Materials [1]

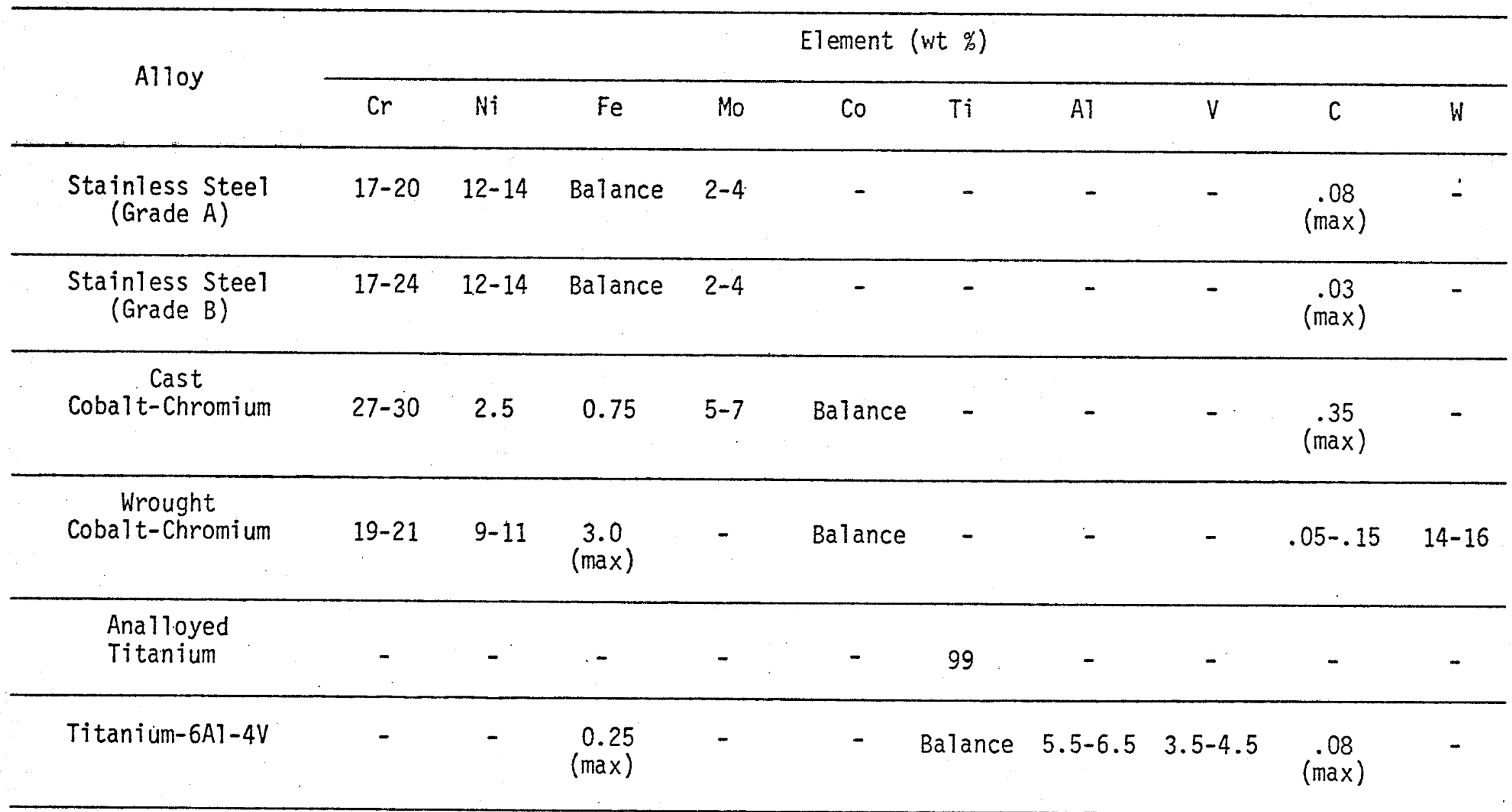




\section{CHAPTER 3}

\section{EXPERIMENTAL}

\subsection{Alloy Preparation}

Approximately $500 \mathrm{gm}$ of alloy were melted in an induction furnace with an Argon atmosphere and cast into an ingot about $125 \mathrm{~mm}$ long and $20 \mathrm{~mm}$ diameter. The nominal composition of the ingot and the material purity is given in Table II. After casting, the ingots were hot swaged at $1100^{\circ} \mathrm{C}$ to the appropriate diameter for the particular test. Following swaging, the material was solution heat treated at $1250^{\circ} \mathrm{C}$ for 4 hours in a double silica tube filled with argon and then quenched in ice water. The specimens were then machined to the appropriate shapes and dimensions. Following machining, the specimens were given a precipitation heat treatment at $800^{\circ} \mathrm{C}$ for ten hours, the conditions for attaining maximum strength [8]. The specimens were given a final polishing with 600 grit emery paper immediately prior to testing.

\subsection{Static Strength}

Duplicate cylindrical tensile specimens with a gauge length of $20 \mathrm{~mm}$ and diameter of $3.4 \mathrm{~mm}$ were tested in tension on an Instron testing machine. The initial strain rate was $4 \times 10^{-4} \mathrm{sec}^{-1}$.

\subsection{Fatigue Strength}

Cylindrical fatigue specimens with a gauge length of $14 \mathrm{~mm}$ and a gauge diameter of $3.5 \mathrm{~mm}$ were tested to failure on an Amsler High 


\section{TABLE II}

Nominal Composition and Material Purity for Co-Ni-Cr-Ti Alloy

$\begin{array}{lccc}\text { Element } & \text { Weight } \% & \text { Atomic } \% & \text { Purity } \\ \text { Cobalt } & 40 & 41.2 & 99.99 \\ \text { Nickel } & 37 & 38.2 & 99.99 \\ \text { Chromium } & 18 & 16.4 & 99.99 \\ \text { Titanium } & 5 & 4.2 & 99.70\end{array}$


Frequency Vibraphone with a cyclic frequency of about $100 \mathrm{cps}$. The specimens were axially loaded and most tests were conducted with loading from zero to peak tensile stress (stress ratio, $R=0$ ). A few tests were conducted with a stress ratio of $R=-1$ (equal compressive and tensile stresses). The peak stresses utilized were in the range $500 \mathrm{MN} / \mathrm{m}^{2}$ $725 \mathrm{MN} / \mathrm{m}^{2}$.

\subsection{In-Vitro Corrosion Testing}

Cylindrical specimens, $8 \mathrm{~mm}$ in diameter and $25 \mathrm{~mm}$ in length, attached to the ASTM electrode holder [9] were used for the in-vitro corrosion tests. The electrolyte used in all in-vitro corrosion tests was Ringer's solution (Table III) prepared such that the ionic concentration of the major elements was similar to that of extracellular fluid (Table III), the environment in which an actual implant is immersed. The electrolyte was prepared from a stock solution of five times concentration from which one litre of Ringer's solution was prepared by appropriate dulution immediately prior to testing. All in-vitro corrosion tests were performed in an electrochemical cell similar in design to that recomnended by the ASTM [9]. All tests were conducted at $37^{\circ} \mathrm{C} \pm 1^{\circ} \mathrm{C}$ maintained by immersing the cell in a temperature regulated water bath and at a $\mathrm{pH}$ of 7.2-7.4 maintained by addition of $1 \mathrm{~N} \mathrm{HCl}$ or $1 \mathrm{~N} \mathrm{NaOH.}$

The amount of dissolved $\mathrm{O}_{2}$ and $\mathrm{CO}_{2}$ gases in extracellular fluid can vary considerably in the vicinity of an implant, particularly in crevices formed between screws and plates. Therefore, in-vitro tests were conducted in several solutions containing various amounts of dissolved 
20.

\section{TABLE III}

Compositions of Ringer's Solution and Extracellular Fluid

Ringer's Solution [10]

Compound

$\mathrm{Na} \mathrm{Cl}$

$\mathrm{Na} \mathrm{H} \mathrm{CO}_{3}$

$\mathrm{KCl}$

$\mathrm{Mg} \mathrm{Cl} 2 \cdot 6 \mathrm{H}_{2} \mathrm{O}$

$\mathrm{Mg} \mathrm{SO}_{4} \cdot 7 \mathrm{H}_{2} \mathrm{O}$

$\mathrm{Na}_{2} \mathrm{HPO}_{4}$

$\mathrm{Na} \mathrm{H} \mathrm{H}_{4} \cdot \mathrm{H}_{2} \mathrm{O}$
Concentration (mg/litre)

6,300

2,440

374

203

123

71

69

Extracellular Fluid [11]

\begin{tabular}{|c|c|c|}
\hline \multirow{2}{*}{ Element } & \multicolumn{2}{|c|}{ Composition } \\
\hline & mg/litre & m Eg./litre \\
\hline $\mathrm{Na}+$ & 3,266 & 142 \\
\hline$k+$ & 145 & 5 \\
\hline $\mathrm{Cl}-$ & 3,605 & 103 \\
\hline $\mathrm{HCO}_{3}^{-}$ & 1,708 & 28 \\
\hline $\mathrm{Ca}++$ & 200 & 5 \\
\hline $\mathrm{Mg}++$ & 72 & 3 \\
\hline
\end{tabular}


gases as indicated in Table IV maintained by bubbling controlled amounts of $\mathrm{O}_{2}, \mathrm{CO}_{2}$ and Argon through the solution. A Radiometer acid-base analyzer, type PHM 71 was used to measure the $0_{2}, \mathrm{CO}_{2}$ concentrations and the $\mathrm{pH}$.

Three types of in-vitro corrosion tests were performed. Cathodic and linear anodic polarization studies to obtain an indication of the corrosion rate of the alloy [12] and cyclic anodic polarization to determine values of rest potential, $E_{R}$, pitting potential, $E_{C}$, and protection potential, $E_{p}$.

a) Cathodic Polarization

Cathodic polarization studies were conducted by passing a cathodic current from a Kiethly Constant Current Source, model \#225, between the specimen and the platinum counter electrodes. The current densities were in the range $0-10 \mu \mathrm{A} / \mathrm{cm}^{2}$ and the system was allowed to stabilize for 5 minutes at each value of current density before the value of potential was measured with respect to a saturated calomel electrode using a Kiethly Digital Multimeter, model \#160.

b) Linear Anodic Polarization

These tests were conducted in a similar manner to those for cathodic polarization except that small anodic current densities $\left(0-2 \mu \mathrm{A} / \mathrm{cm}^{2}\right)$ were utilized so that the potential change from the rest potential . was linear with current density and in the order of $10 \mathrm{mv}$.

c) Cyclic Anodic Polarization Cyclic potentiodynamic anodic polarization curves at a scan rate of $600 \mathrm{mv} /$ hour were obtained using a Wenking Potentiostat, model \#68TS3, 
22.

TABLE IV

$\mathrm{O}_{2}$ and $\mathrm{CO}_{2}$ Concentrations for In-Vitro Corrosion Tests

\begin{tabular}{lccc}
\hline Designation & $\begin{array}{c}\text { Concentration } \\
(\mathrm{mm} \mathrm{Hg})\end{array}$ & Designation & $\begin{array}{c}\text { Concentration } \\
(\mathrm{mm} \mathrm{Hg})\end{array}$ \\
\hline Low $\mathrm{CO}_{2}$ & $<8$ & Low $\mathrm{O}_{2}$ & $<10$ \\
Medium $\mathrm{CO}_{2}$ & $40-60$ & Medium $\mathrm{O}_{2}$ & $80-120$ \\
High $\mathrm{CO}_{2}$ & $90-110$ & High $0_{2}$ & $250-300$ \\
\hline
\end{tabular}

TABLE V

Tensile Properties of Co-Ni-Cr-Ti Alloy

Ultimate Strength

$\left(\mathrm{MN} / \mathrm{m}^{2}\right)$
$0.2 \%$ offset

Yield Strength

$\left(\mathrm{MN} / \mathrm{m}^{2}\right)$
Elongation

$(\%)$ 
and an Erwin Halstrup Motorpotentiometer, model \#MP165. A schematic of the circuitry is shown in Figure 1. All runs were conducted in duplicate. The current was monitored continuousiy via the potentiostat recorder terminals using a Rikadenki, model \#B-104, strip chart recorder. The potential scan was reversed when the current density reached a value about 2 orders of magnitude greater than the current density at the pitting or breakdown potential.

\subsection{In-Vivo Corrosion Testing}

Cylindrical specimens about $4 \mathrm{~mm}$ in length and $3 \mathrm{~mm}$ in diameter were accurately weighed on a Sartorius microbalance which weighs to $10^{-5}$ grams and implanted in the thigh tissues of three month old New Zealand white rabbits. Some control specimens of type $316 \mathrm{~L}$ stainless steel were also implanted in the opposite thigh. The animals were sacrificed at implantation times from 6 - 17 months and the pellets removed, cleaned and weighed. Samples of surrounding tissue were also removed for pathological examination. 
SCHEMATIC CIRCUITRY FOR POTENTIODYNAMIC POLARIZATION

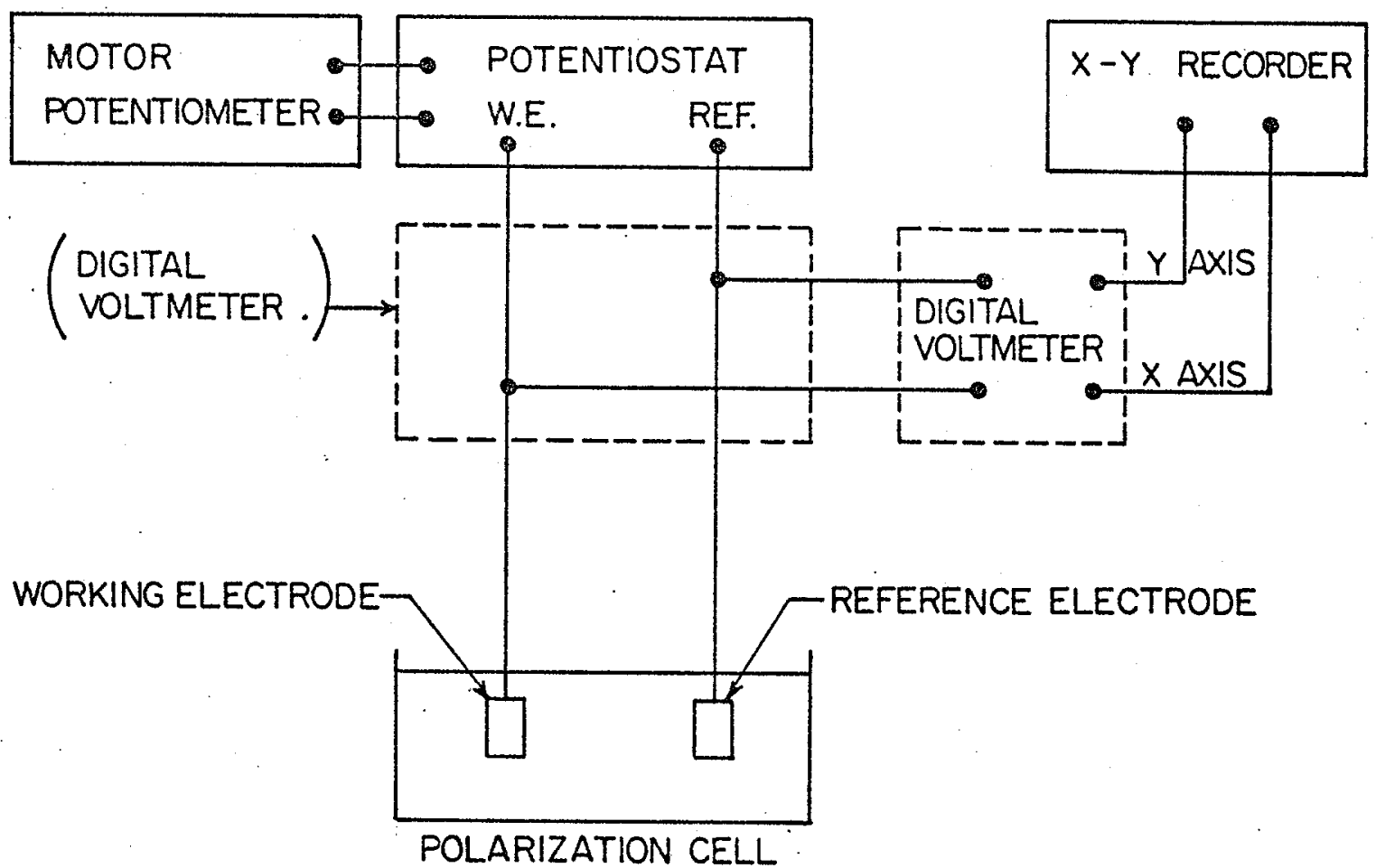

Fig. 1 


\section{CHAPTER 4}

\section{RESULTS}

\subsection{Static Strength}

The tensile properties of the duplicate specimens were virtually identical and are given in Table $V$ (see Page 22).

\subsection{Fatigue Strength}

The fatigue life for the $\mathrm{Co}-\mathrm{Ni}-\mathrm{Cr}-\mathrm{Ti}$ alloy at various peak stress levels is given in Table $V I$ for a stress ratio $R=0$ and Table VII for $R=-1$. The $S-N$ curves are compared with that for annealed stainless steel in Fig. 2 .

\subsection{In-Vitro Corrosion Testing}

a) Cathodic Polarization

An estimate of the corrosion current density can be obtained by Tafel extrapolation of the linear portion of the cathodic polarization curve to the rest potential, $E_{R}[12]$. Cathodic polarization curves for three $\mathrm{O}_{2}$ and $\mathrm{CO}_{2}$ concentrations are given in Fig. 3 and the results are summarized in Table VIII.

b) Linear Anodic Polarization

The linear anodic polarization curves for three $\mathrm{O}_{2}$ and $\mathrm{CO}_{2}$ concentrations are shown in Fig. 4. The corrosion current can be estimated from the slope (polarization resistance) of the linear anodic polarization curve using the reitation [12]: 


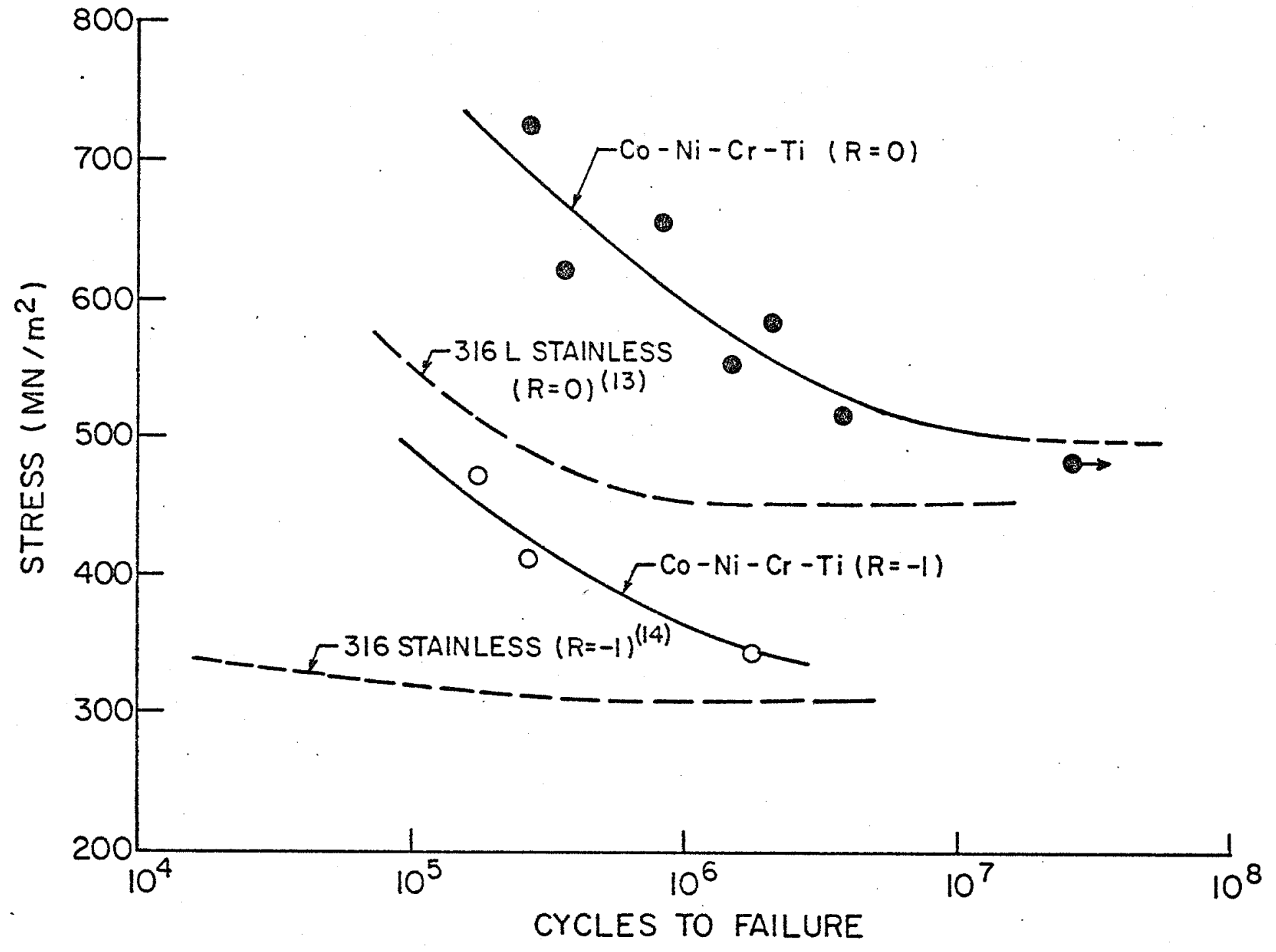

Fig. 2 


\section{TABLE VI}

Fatigue Life of Co-Ni-Cr-Ti Alloy at Stress Ratio $\mathrm{R}=0$

$\begin{gathered}\text { Peak Stress } \\ \left(\mathrm{MN} / \mathrm{m}^{2}\right)\end{gathered}$
483

518

552

587

621

656

725
Fatigue Life

(Cycles)

$2.6 \times 10^{7}$

(did not fail)

$3.8 \times 10^{6}$

$1.5 \times 10^{6}$

$2.1 \times 10^{6}$

$3.9 \times 10^{5}$

$8.3 \times 10^{5}$

$2.9 \times 10^{5}$

\section{TABLE VII}

Fatigue Life of Co-Ni-Cr-Ti Alloy at Stress Ratio $\mathrm{R}=-1$

Peak Stress

$\left(\mathrm{MN} / \mathrm{m}^{2}\right)$

345

414

483
Fatigue Life

(Cycles)

$1.7 \times 10^{6}$

$2.7 \times 10^{5}$

$1.8 \times 10^{5}$ 


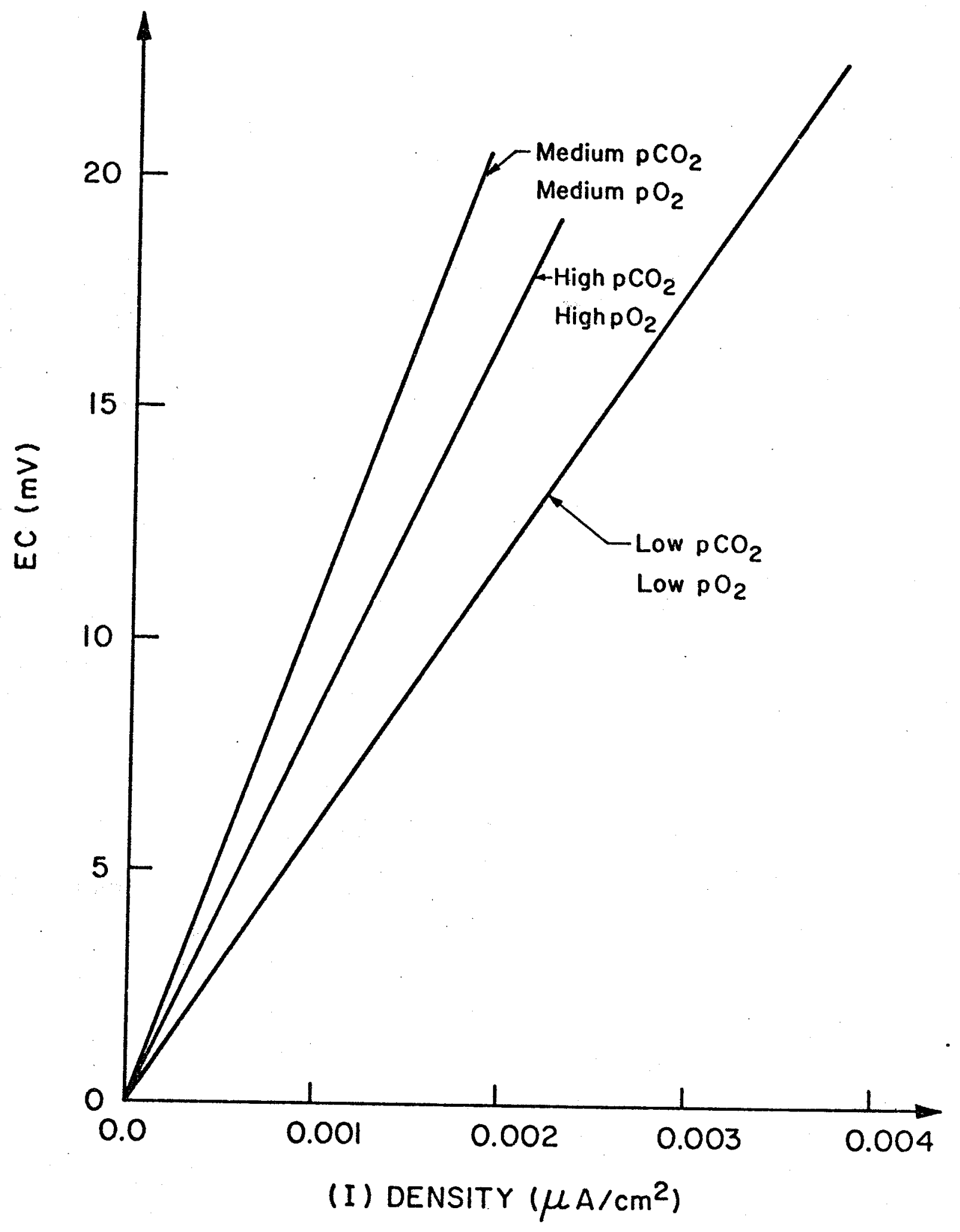

Fig. 3. ANODIC POLARIZATION CO-Ni-Cr-Ti . 
TABLE VIII

Cathodic and Linear Polarization Results CO-Ni-Cr-Ti Alloy

\begin{tabular}{lccccc}
\hline $\mathrm{O}_{2}$ Concentration & $\mathrm{CO}_{2}$ Concentration & $\begin{array}{c}\text { Cathodic Tafel } \\
\text { Slope } \\
(\mathrm{V} / \text { decade })\end{array}$ & $\begin{array}{c}\text { Corrosion Current } \\
\text { Tafel Extrapolation } \\
\left(\mu \mathrm{AA} / \mathrm{cm}^{2}\right)\end{array}$ & $\begin{array}{c}\text { Polarization } \\
\text { Resistance } \\
\left(\mathrm{V} / \mu \mathrm{A} / \mathrm{cm}^{2}\right)\end{array}$ & $\begin{array}{c}\text { Corrosion } \\
\text { Current from } \\
\text { Eq. } \\
\left(\mu \mathrm{A} / \mathrm{cm}^{2}\right)\end{array}$ \\
\hline Low & Low & .310 & $1.07 \times 10^{-2}$ & 7 & $1.9 \times 10^{-2}$ \\
Medium & Medium & .230 & $4.2 \times 10^{-3}$ & 11 & $4.2 \times 10^{-3}$ \\
High & High & .230 & $1.3 \times 10^{-2}$ & 8 & $1.4 \times 10^{-2}$ \\
\hline
\end{tabular}




$$
I_{\text {corr }}=\frac{B_{a} B_{c}}{2.3\left(B_{a}+B_{c}\right)(\Delta E / \Delta I)}
$$

where $I_{\text {corr }}=$ corrosion current density

$\mathrm{B}_{\mathrm{a}} \quad=$ anodic Tafel slope (volts/decade of current)

$B_{C}=$ cathodic Tafel slope (volts/decade of current)

$\frac{\Delta \mathrm{E}}{\Delta \mathrm{I}}=$ slope of the linear anodic polarization curve

The rest potential of the $\mathrm{Co}-\mathrm{Ni}-\mathrm{Cr}-\mathrm{Ti}$ alloy lies in a passive region where the anodic Tafel slope, $B_{a}$, is very large (see Fig. 7) and therefore if $B_{a}$ approaches infinity, Eq. (1) reduces to:

$$
I_{\text {corr }} \approx \frac{B_{C}}{2.3(\Delta E / \Delta I)} \text {. }
$$

The cathode Tafel slopes, $B_{c}$, obtained from Fig. 4, the polarization resistance, $\Delta E / \Delta \mathrm{I}$, and the corrosion current, $I_{c o r r}$, calculated from Eq. (2) are given in Table VIII.

c) Cyclic.Anodic Polarization

Cyclic anodic polarization curves were obtained in duplicate for various $\mathrm{CO}_{2}$ and $\mathrm{O}_{2}$ concentrations. These polarization curves (Figures $5-13$ ) show the values of rest or corrosion potential, $E_{R}$, pitting or breakdown potential, $E_{c}$, and protection potential, $E_{p}$. The protection potential, $E_{p}$, is defined as the potential at which, on the return voltage scan, the current density equals that on the forward scan. In the cases where the protection potential is lower (more active) than the rest potential, $E_{R}$, the protection potential, $E_{p}$, is defined as the potential at which the current density became cathodic on the return 


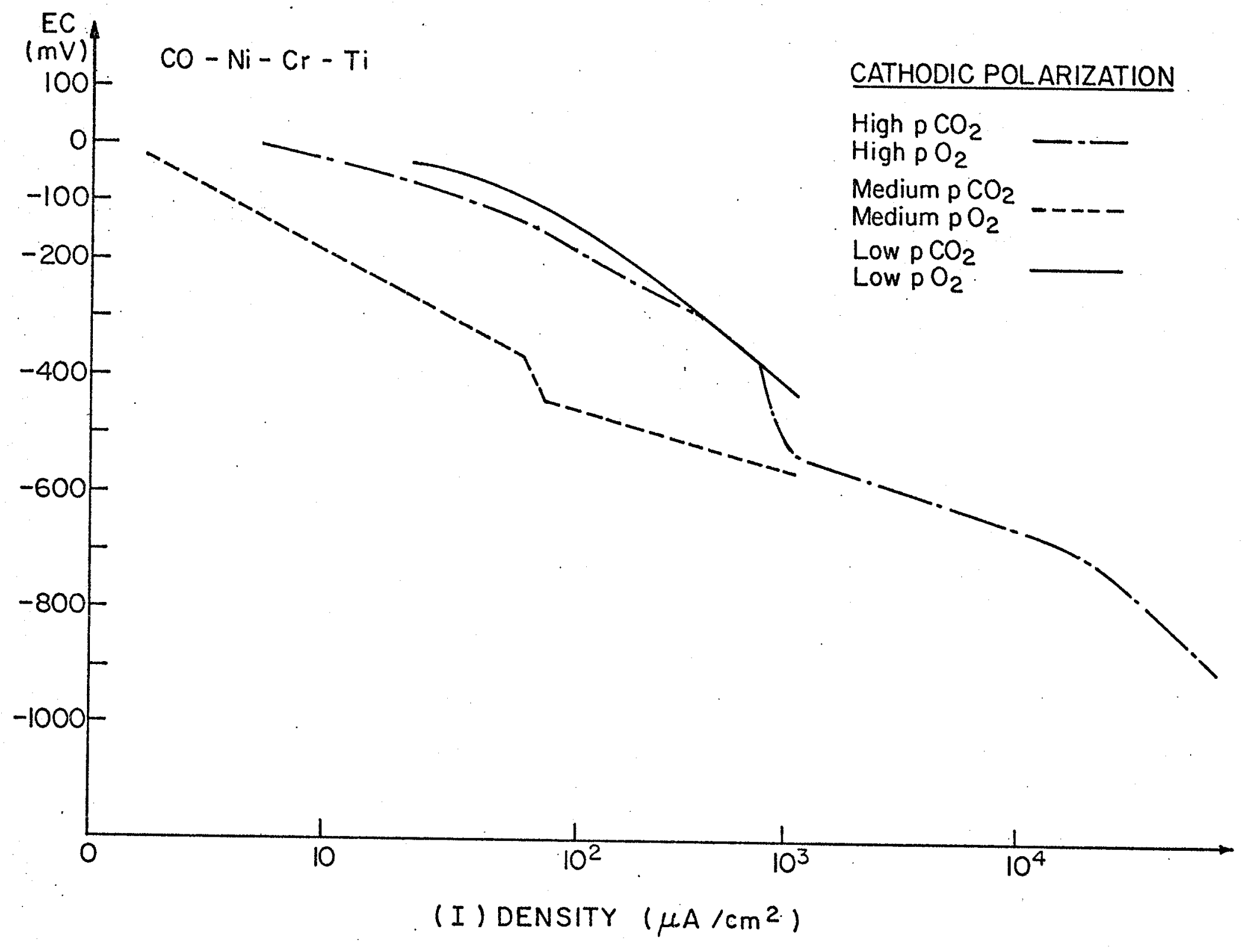

Fig. 4 


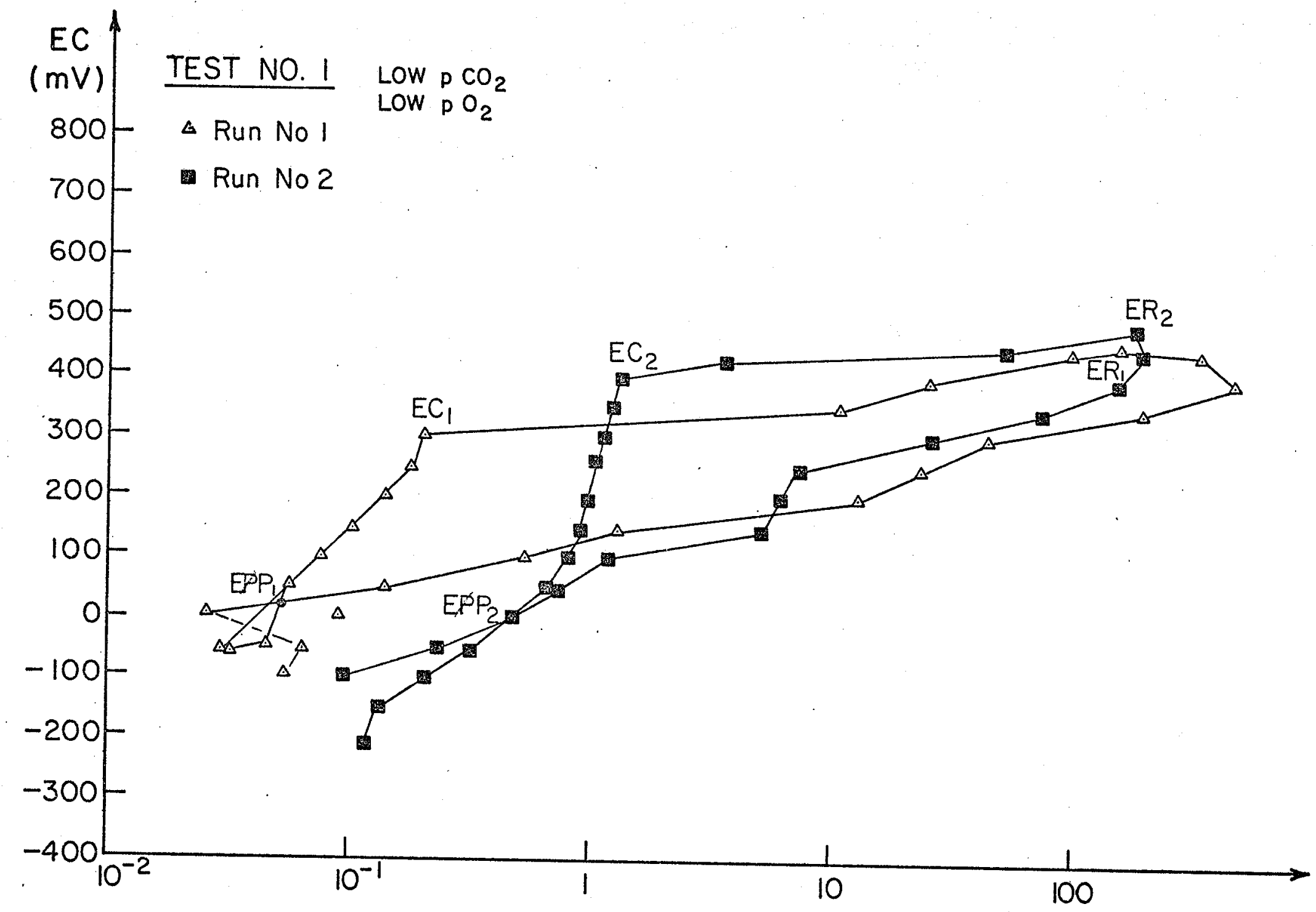

(I) DENSITY $\left(\mu \mathrm{A} / \mathrm{cm}^{2}\right)$

Fig. 5 Cyclical Potentiodynamic Scan. 


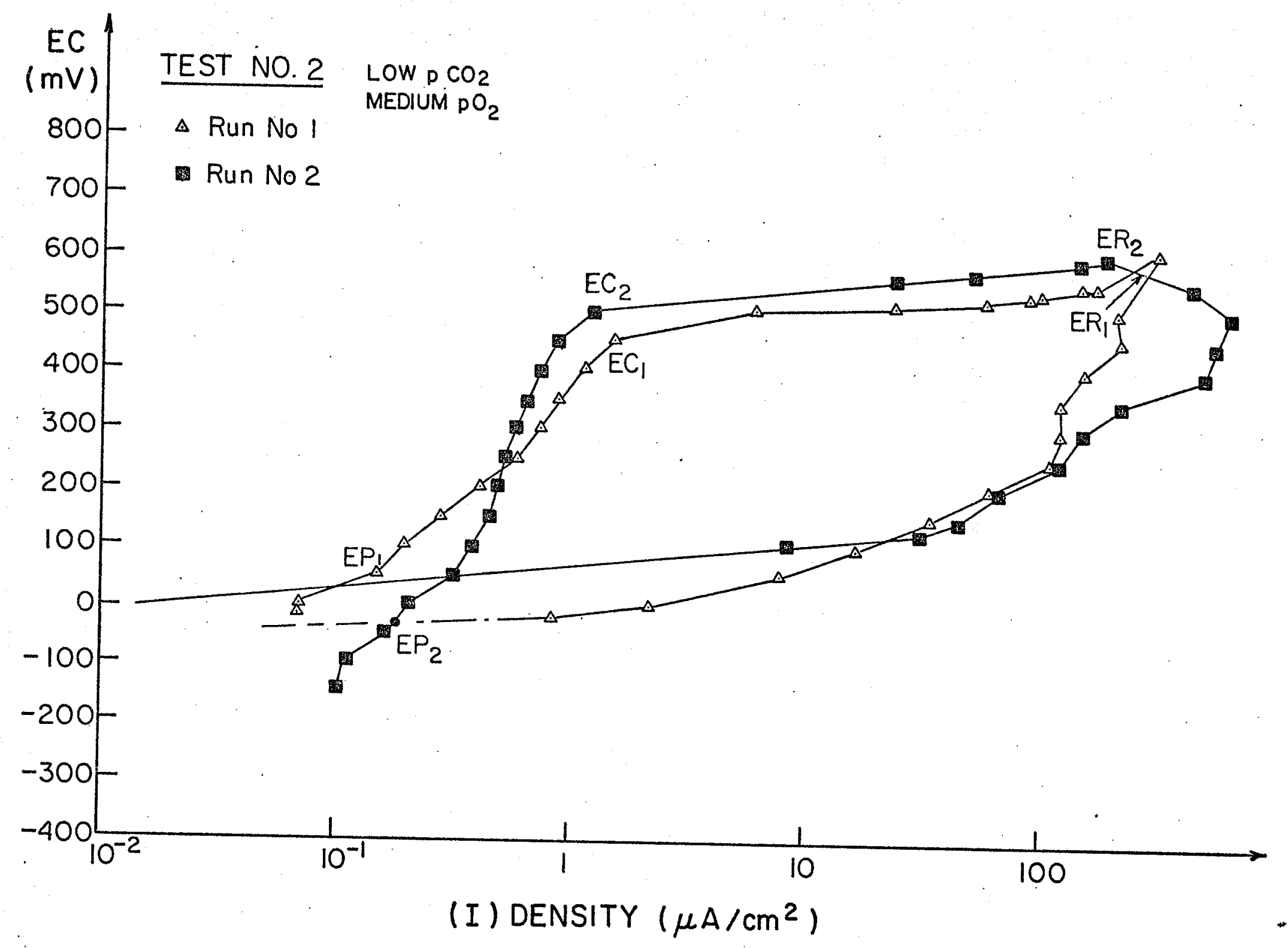

Fig. 6 Cyclical Potentiodyramic Scan. 


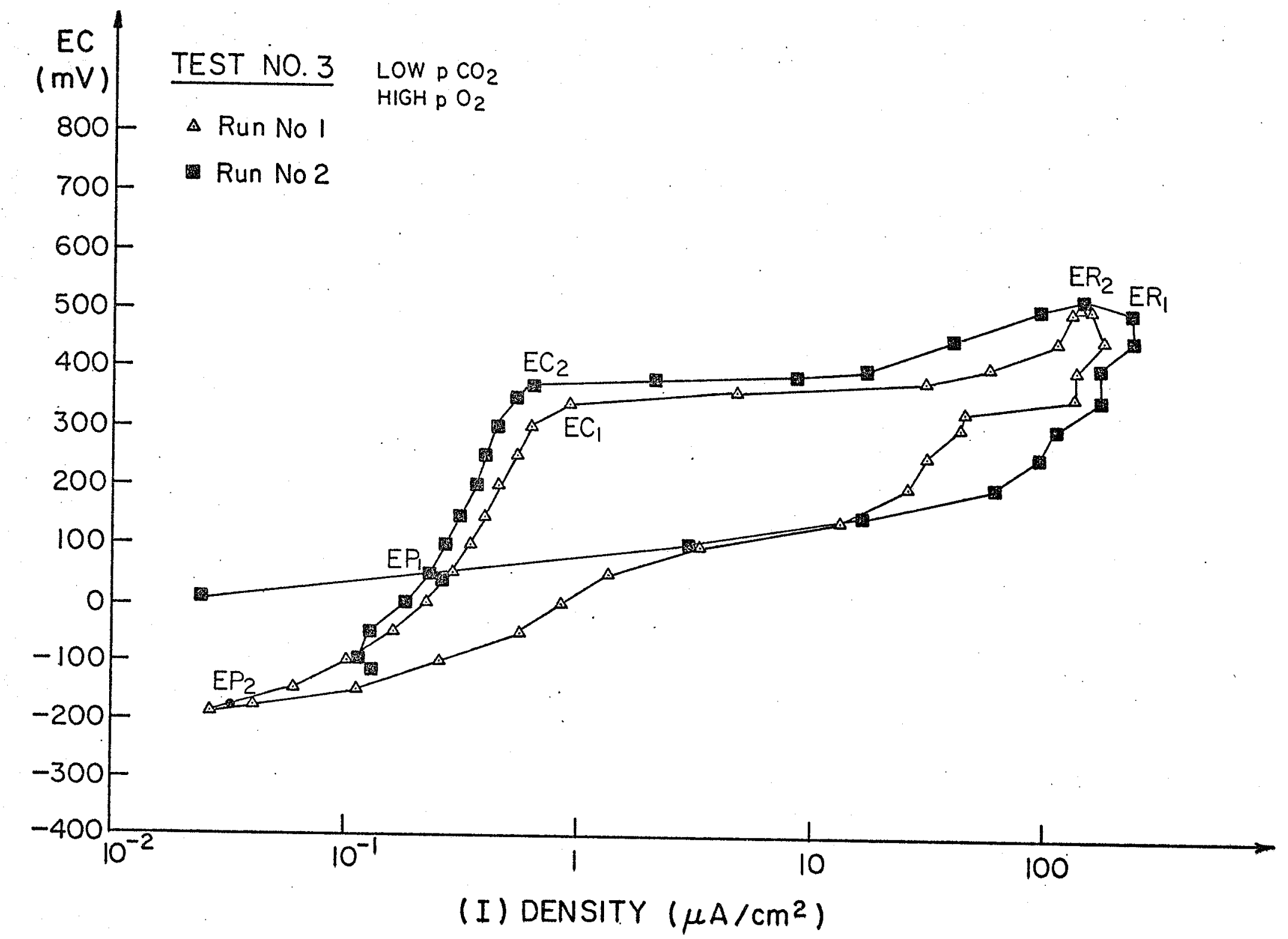

Fig. 7 Cyclical Potentiodynamic Scan. 


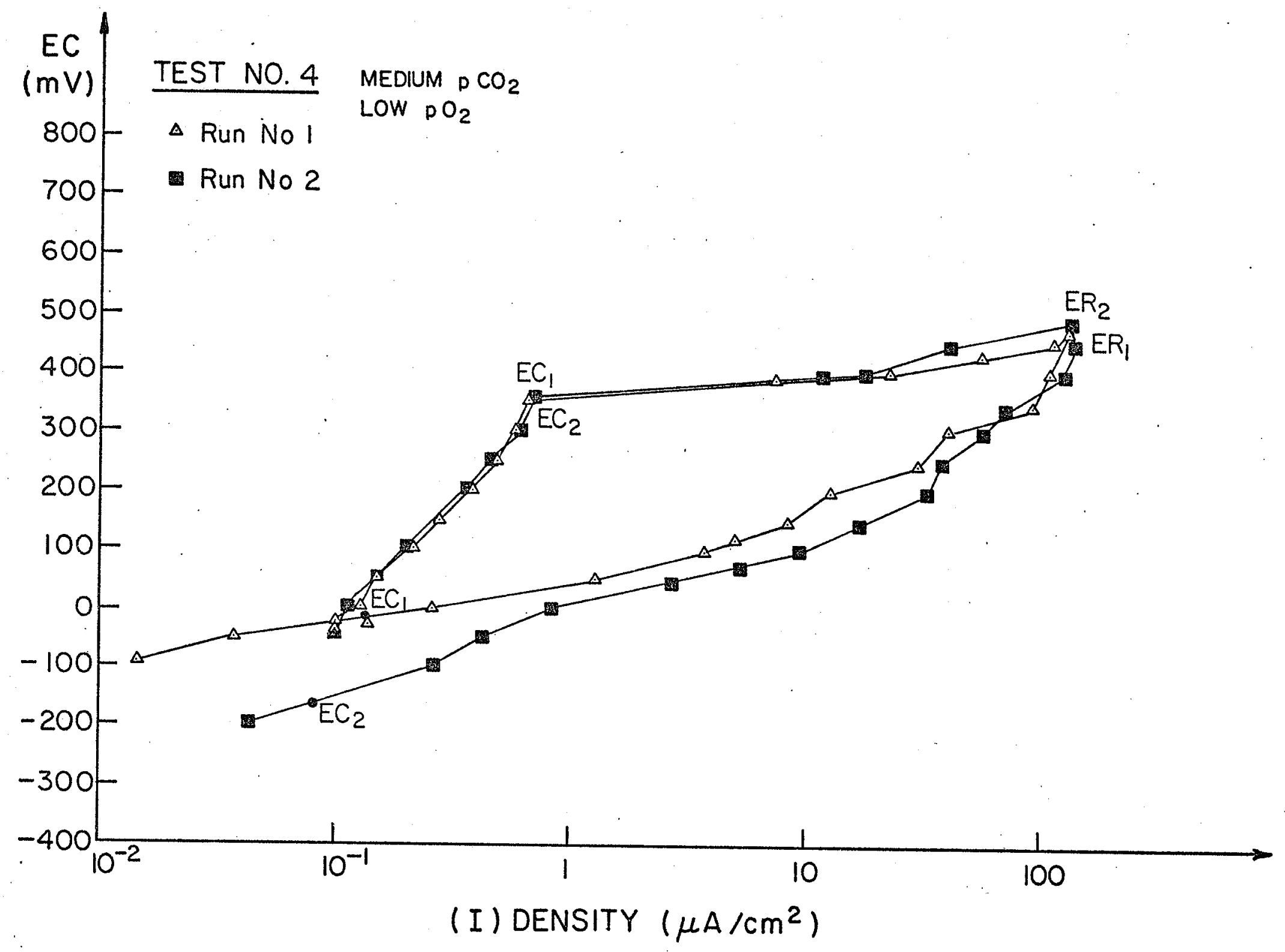

Fig. 8 Cyclical Potentiodynamic Scan. 


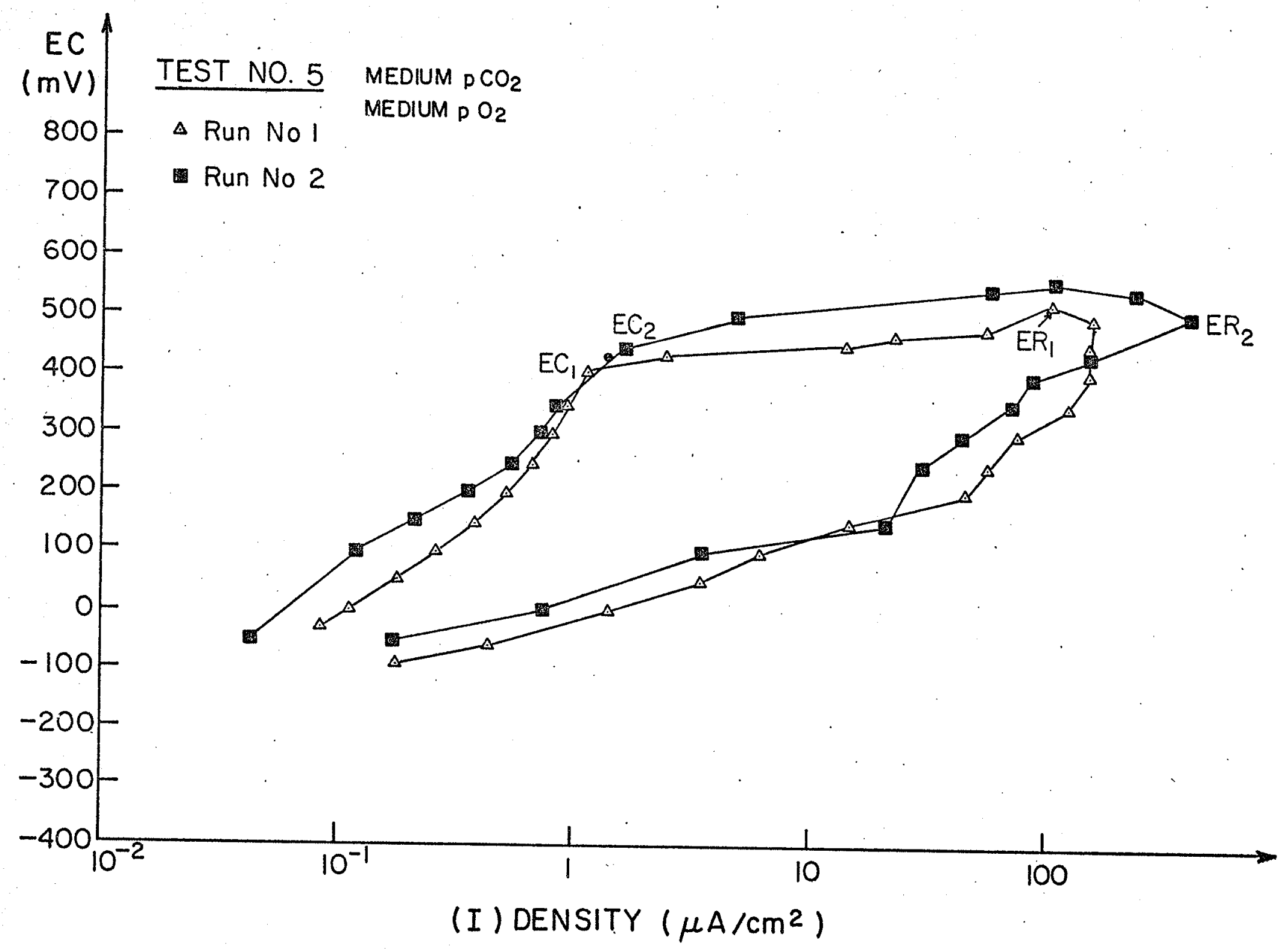

Fig. 9 Cyclical Potentiodynamic Scan. 


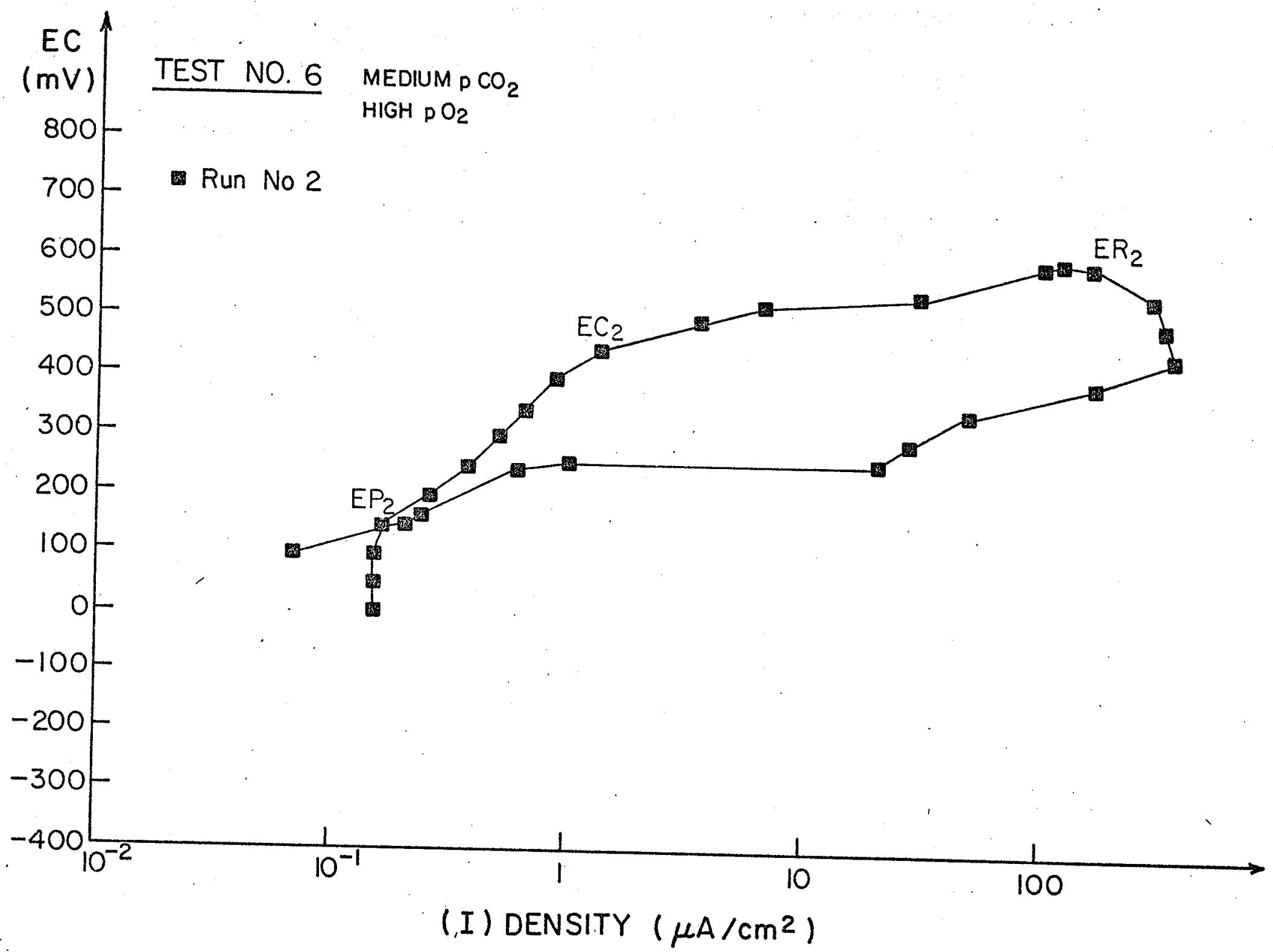

Fig. 10 Cyclical Potentiodynamic Scan. 


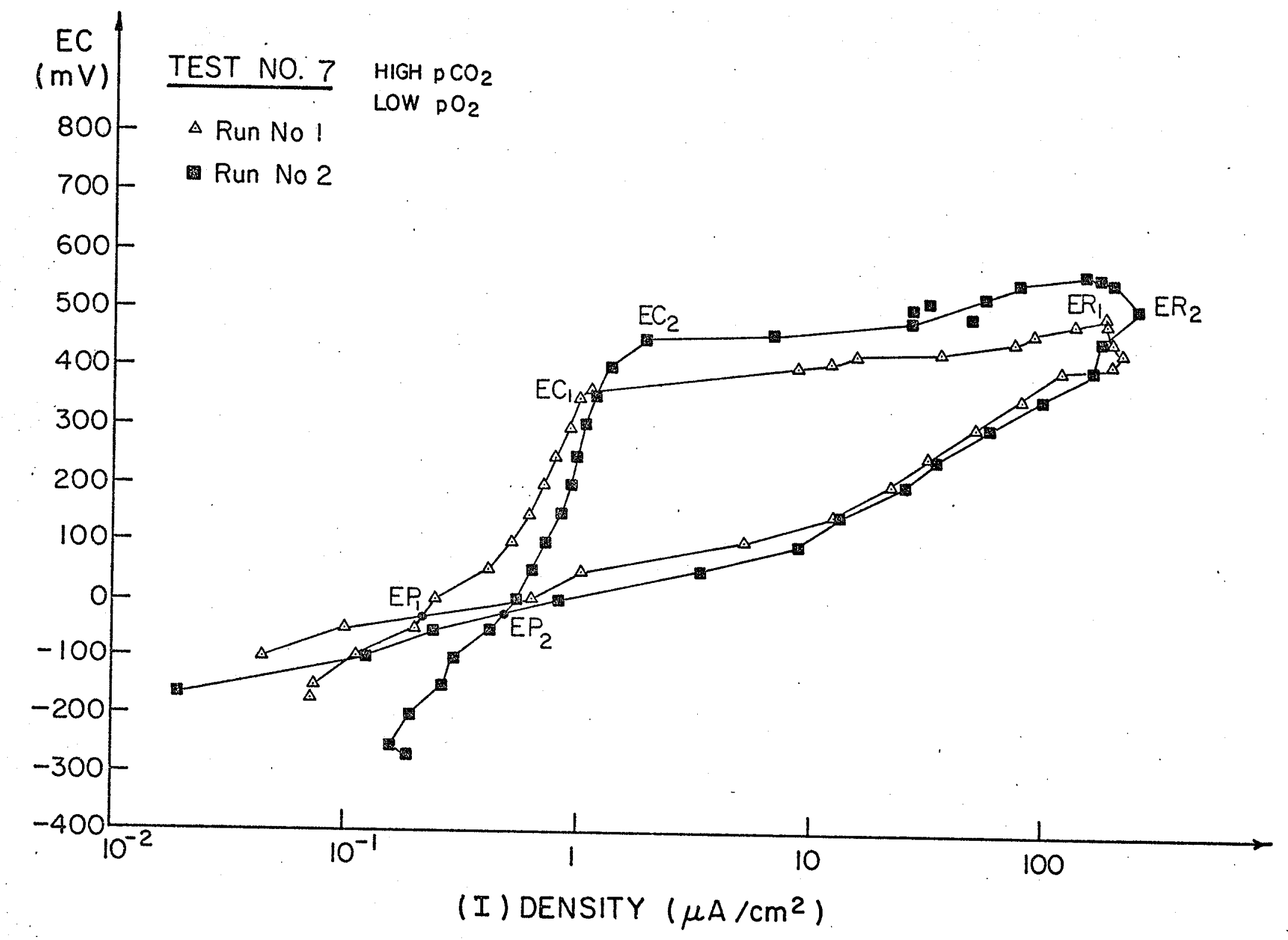

Fig. 11

Cyclical Potentiodynamic Scan. 


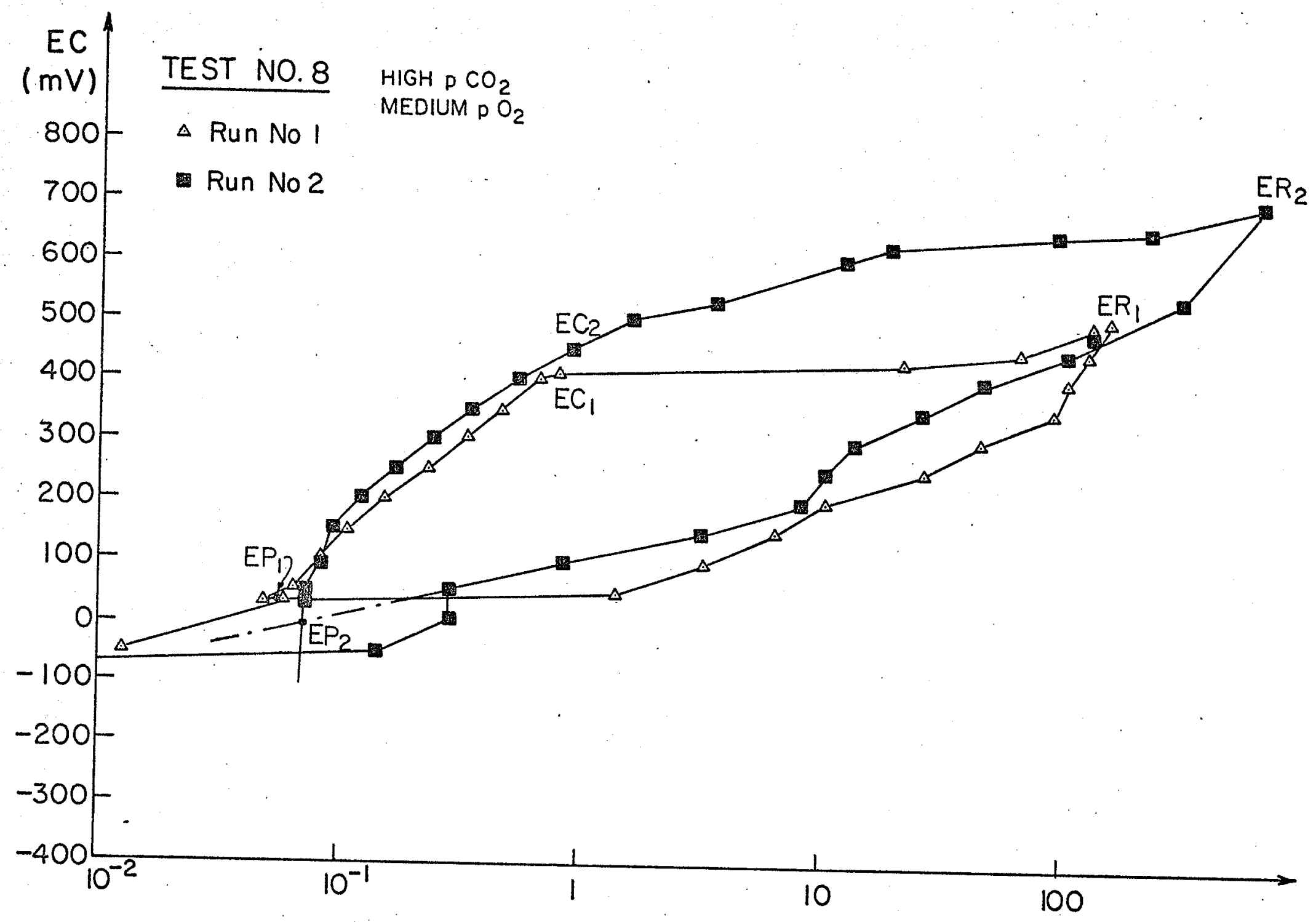

(I) DENSITY $\left(\mu \mathrm{A} / \mathrm{cm}^{2}\right)$

Fig. 12 Cyclical Potentiodynamic Scan. 


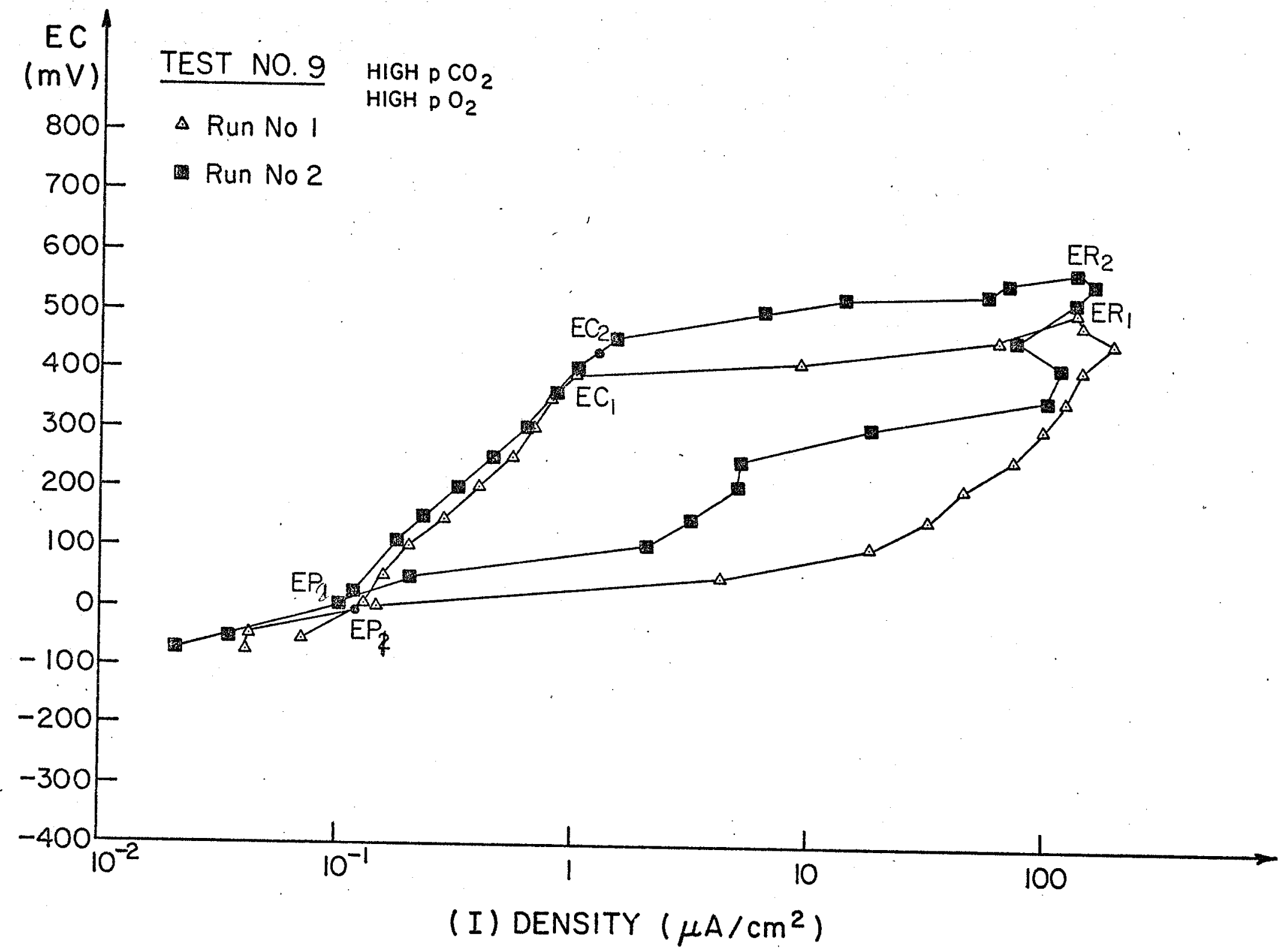

Fig. 13

Cyclical Potentiodynamic Scan. 
scan. The results for the polarization curves obtained at various $\mathrm{CO}_{2}$ and $\mathrm{O}_{2}$ concentrations are summarized in Table IX and in Figs. $5-13$. The values obtained for $E_{R}, E_{c}$ and $E_{p}$ in Table IX generally agreed to

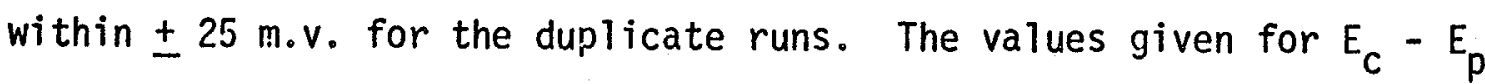
and $E_{C}-E_{R}$ are therefore likely accurate to $\pm 50 \mathrm{~m} . \mathrm{v}$.

\subsection{In-Vivo Corrosion Studies}

The corrosion data for the Co-Ni-Cr-Ti alloy implants and the type $316 \mathrm{~L}$ stainless steel control implants are given in Table $X$. All pellets were shiny upon removal with no evidence of corrosion or pitting. The pathological studies of adjacent tissue showed no adverse tissue reaction for either $\mathrm{CO}-\mathrm{Ni}-\mathrm{Cr}-\mathrm{Ti}$ or stainless steel implants. A typical pathological report follows:

"An irregular fragment of firm, resiliant, translucent white tissue measuring. $2.5 \times 1 \times 1.3 \mathrm{~cm}$ was received. Embedded within it was a smooth, glistening metal pellet measuring $0.4 \mathrm{~cm}$ in diameter and $0.35 \mathrm{~cm}$ in length. The walls of the cavity in which the pellet was embedded were smooth and glistening.

The thin capsule which surrounded the cylindrical metal pellet consisted of a thin layer of avascular fibrous tissue approximately 16 microns in thickness. Ho inflammatory or reactive change was evident in the adjacent adipose tissue or muscle."

Because of the inherent inaccuracies involved in weight loss experiments, the values given in Table $X$ are quite subjective but they do indicate that the corrosion rate is very small. 
TABLE IX

Summary of Cyclic Anodic Polarization Results on Co-Ni-Cr-Ti Alloy

\begin{tabular}{|c|c|c|c|c|c|}
\hline $\begin{array}{l}\mathrm{O}_{2} \text { and } \mathrm{CO}_{2} \\
\text { Concentrations }\end{array}$ & $\begin{array}{c}\text { Rest } \\
\text { Potential } \\
\mathrm{E}_{\mathrm{R}} \\
\text { (mv vs. S.C.E.) (mv } \\
\end{array}$ & $\begin{array}{cc}\text { Breakdown } & P \\
\text { Potential } & P \\
E_{c} & \\
\text { vs. S.C.E.) (mv } \\
\end{array}$ & $\begin{array}{l}\text { Protection } \\
\text { Potential } \\
E_{p} \\
\text { vs. S.C.E.) }\end{array}$ & $\begin{array}{l}E_{c}-E_{p} \\
(m \cdot v \cdot) \\
\end{array}$ & $\begin{array}{l}E_{c}-E_{R} \\
\text { (m.v.) }\end{array}$ \\
\hline $\begin{array}{l}\text { Low } \mathrm{CO}_{2} \\
\text { Low } \mathrm{O}_{2}\end{array}$ & -132 & 350 & +10 & 340 & 482 \\
\hline $\begin{array}{l}\text { Low } \mathrm{CO}_{2} \\
\text { Medium } \mathrm{O}_{2}\end{array}$ & -82 & 450 & -3 & 453 & 535 \\
\hline $\begin{array}{l}\text { Low } \mathrm{CO}_{2} \\
\mathrm{High} \mathrm{O}_{2}\end{array}$ & -154 & 355 & -90 & 450 & 604 \\
\hline $\begin{array}{l}\text { Medium } \mathrm{CO}_{2} \\
\text { Low } \mathrm{O}_{2}\end{array}$ & -38 & 355 & -90 & 455 & 483 \\
\hline $\begin{array}{l}\text { Medium } \mathrm{CO}_{2} \\
\text { Medium } \mathrm{O}_{2}\end{array}$ & -69 & 423 & -101 & 524 & 593 \\
\hline $\begin{array}{l}\text { Medium } \mathrm{CO}_{2} \\
\text { High } \mathrm{O}_{2}\end{array}$ & -18 & 400 & -40 & 440 & 458 \\
\hline $\begin{array}{l}\text { High } \mathrm{CO}_{2} \\
\text { LoW } \mathrm{O}_{2}\end{array}$ & -176 & 395 & -12 & 407 & 583 \\
\hline $\begin{array}{l}\text { High } \mathrm{O}_{2} \\
\text { Medium } \mathrm{O}_{2}\end{array}$ & +30 & 430 & +7 & 423 & 453 \\
\hline $\begin{array}{l}\mathrm{High} \mathrm{CO}_{2} \\
\mathrm{High} \mathrm{O}_{2}\end{array}$ & -39 & 400 & -1 & 401 & 440 \\
\hline
\end{tabular}




\section{TABLE $X$}

Results of In-Vivo Corrosion Studies on $\mathrm{CO}-\mathrm{Ni}-\mathrm{Cr}-\mathrm{Ti}$ Alloy

\begin{tabular}{lcccc} 
Implant Alloy & $\begin{array}{c}\text { Duration of } \\
\text { Implantation } \\
\text { (Days) }\end{array}$ & $\begin{array}{c}\text { Weight Upon } \\
\text { Implantation } \\
\text { (gms) }\end{array}$ & $\begin{array}{c}\text { Weight Upon } \\
\text { Removal } \\
\text { (gms) }\end{array}$ & $\begin{array}{c}\text { Weight Loss } \\
\text { (gms) }\end{array}$ \\
\hline Co-Ni-Cr-Ti & 170 & 0.48495 & 0.48495 & 0 \\
Co-Ni-Cr-Ti & 189 & 0.51624 & 0.51624 & 0 \\
Co-Ni-Cr-Ti & 439 & 0.43606 & 0.43600 & $6 \times 10^{-5}$ \\
$\begin{array}{l}\text { Co-Ni-Cr-Ti } \\
\text { Type 316 L }\end{array}$ & 469 & 0.50846 & 0.50842 & $4 \times 10^{-5}$ \\
$\begin{array}{l}\text { Stainless Steel } \\
\text { Type 316 L }\end{array}$ & 170 & 0.34565 & 0.34565 & 0 \\
$\begin{array}{l}\text { Stainless Steel } \\
\text { Type 316 L }\end{array}$ & 189 & 0.41378 & 0.41378 & 0 \\
Stainless Steel & 469 & 0.38488 & 0.38481 & $7 \times 10^{-5}$ \\
\hline
\end{tabular}




\section{CHAPTER $V$}

\section{DISCUSSION}

\subsection{Discussion}

The tensile properties of the Co-Ni-Cr-Ti alloy (Table v) exceed the minimum ASTM requirements of $896 \mathrm{MN} / \mathrm{m}^{2}$ ultimate strength and $379 \mathrm{MN} / \mathrm{m}^{2}$ yield strength for wrought cobalt-chromium alloys [1]. No ductility limits are specified in the ASTM standard for wrought cobalt-chromium alloys but the elongation of $19 \%$ greatly exceeds the $8 \%$ minimum specified for cast cobalt-chromium-molybdenum alloys [1]. No fatigue strength data are included in the ASTM specifications but the fatigue. strength of the $\mathrm{Co-Ni-Cr-Ti}$ alloy exceeds that of type $316 \mathrm{~L}$ stainless steel as shown in Fig. 1. Therefore, the Co-Ni-Cr-Ti alloy likely has sufficient strength for use as a surgical implant material.

Corrosion rates for the $\mathrm{CO}-\mathrm{Ni}-\mathrm{Cr}-\mathrm{Ti}$ alloy can be estimated from the corrosion currents given in Table VIII and Faraday's laws of electrolysis. The corrosion rate can be calculated from:

$$
R=\frac{W \times I_{\text {corr }} \times A}{V \times 96,500}
$$

where $R=$ corrosion rate $(\mathrm{gms} / \mathrm{sec})$

$W \quad=$ atomic weight

$I_{\text {corr }}=$ corrosion current density (amps $/ \mathrm{cm}^{2}$ )

$A=$ surface area $\left(\mathrm{cm}^{2}\right)$

$V \quad=$ valence of metal 
The atomic weight, $\mathrm{W}$, of the $\mathrm{Co}-\mathrm{Ni}-\mathrm{Cr}-\mathrm{Ti}$ alloy can be calculated as $52.2 \mathrm{gms} / \mathrm{mole}$ from the data in Table II, the corrosion current is approximately $10^{-8} \mathrm{amps} / \mathrm{cm}^{2}$ from Table VIII, the surface area of the implanted specimens is about $0.5 \mathrm{~cm}^{2}$, and the valence is approximately 2 since both cobalt and nickel have this value.

The calculated corrosion rate for the implanted specimens is therefore:

$$
R=\frac{52 \times 10^{-8} \times 0.5}{2 \times 96,500} \approx 1.4 \times 10^{-12} \mathrm{gms} / \mathrm{sec}
$$

For an implantation time of 469 days the calculated corrosion loss is therefore about $5 \times 10^{-5} \mathrm{gms}$. This value is essentially identical with the actual measured values for implanted specimens (Table $X$ ). Because of the inherent inaccuracies in measuring the very small weight losses involved, the agreement between the calculated and experimental results may be largely fortuitous. However, it is clear that the corrosion rate. of the Co- $\mathrm{Ni}-\mathrm{Cr}-\mathrm{Ti}$ alloy is very low and certainly not appreciably greater than that of present surgical implant materials.

The potentiodynamic anodic polarization results (Table IX) indicate that the rest or corrosion potential of the alloy is in the order of $-50 \mathrm{mv}$ vs S.C.E. and the breakdown or pitting potential, $E_{c}$, is over $440 \mathrm{m.v}$. higher (more noble) than the rest potential with the concentrations of $\mathrm{CO}_{2}$ and $\mathrm{O}_{2}$ in solution having no consistent effect on the values of any of the potentials.

It is known that the breakdown potential of an implant alloy must be substantially above (more noble than) the rest or corrosion 
46.

potential in order to avoid pitting corrosion during service but the minimum value of $E_{C}-E_{R}$ which prevents pitting corrosion is not known. However, pitting corrosion has been known to occur in austenitic stainless steel implants [2] where the breakdown potential is about $350 \mathrm{mv}$ more noble than the rest potential $[5,10]$ (tested under the same conditions as the CO-Ni-Cr-Ti alloy) and therefore the value of $350 \mathrm{mv}$ would seem to be about the minimum acceptable value for the separation between the corrosion and breakdown potentials. The separation of $440 \mathrm{mv}$ for the $\mathrm{CO}-\mathrm{Ni}-\mathrm{Cr}-\mathrm{Ti}$ alloy would therefore appear to be adequate for surgical implant applications.

The severity of, or susceptibility to, crevice corrosion of an alloy has been shown to be related to the nobility of the protection potential, $E_{p}$, or, more exactly, the magnitude of the difference between the breakdown and protection potentials $[15,16]$, with the severity or susceptibility increasing with an increase in the difference between the breakdown and protection potentials. Again, a minimum value for the difference between breakdown and protection potentials to render a materialimmune to crevice corrosion has not been established but cobaltChromium alloys which are relatively, but not completely, immune to crevice corrosion [3] in surgical implant applications have a difference potential of about $100 \mathrm{mv}$ [10]. On the other hand, austenitic stainless steel which is very prone to crevice corrosion $[3,4]$ has a difference potential of about $400 \mathrm{mv}$ [10]. Therefore, it would appear that a difference potential of about $100 \mathrm{mv}$ is the maximum allowable to render an implant alloy relatively immune to crevice corrosion. 
The cyclic anodic polarization results for the Co-Ni-Cr-Ti alloy (Table IX) show the value of protection potential for this alloy is quite active resulting in a large difference potential, $E_{c}-E_{p}$, of about $400 \mathrm{mv}$, very similar to the value obtained for austenitic stainless steel tested under similar conditions $[5,10]$. It is suggested, therefore, that the Co-Ni-Cr-Ti alloy would suffer from crevice corrosion in multi-component implants to about the same degree as those manufactured from austenitic stainless steel. However, in vivo studies would have to be performed to substantiate this.

The strength and corrosion tests indicate that the $\mathrm{Co}-\mathrm{Ni}-\mathrm{Cr}-\mathrm{Ti}$ precipitation hardening alloy has equivalent or superior properties compared with present implant materials. Being a wrought alloy and having good ductility the problems of porosity and low ductility evident in some casting alloys are also avoided. Cyclic anodic polarization studies indicate that the alloy may, however, be susceptible to crevice corrosion to about the same degree as austenitic stainless steel. It is important to note that there appear to be no inherent difficulties with the use of precipitation hardening alloys per se for surgical implants and therefore it may be possible to introduce implant materials with much better strength and corrosion resistance than present materials. The only drawback of the CO-Ni-Cr-Ti alloy investigated in this investi- . cation is its potential susceptibility to crevice corrosion. However, since $\mathrm{Co}-\mathrm{Cr}$ alloys with little or no $\mathrm{Ni}$ content are relatively immune to crevice corrosion it should be possible to develop precipitation hardening alloys which contain little or no $\mathrm{Ni}$ and thereby obtain an alloy 
48.

which has high strength, good general corrosion resistance, and good resistance to crevice corrosion as well. 


\section{CHAPTER VI}

CONCLUSIONS

\subsection{Conclusions}

Upon evaluation of the experimental data for the precipitation hardened $\mathrm{CO}-\mathrm{Ni}-\mathrm{Cr}-\mathrm{Ti}$ alloy it is possible to draw the following conclusions concerning the suitability of a precipitationed hardened alloy for surgical implant applications:

1. The static and fatigue strengths of the alloy are equivalent or superior to those exhibited by present implant materials.

2. The corrosion resistance of the alloy with respect to corrosion current and breakdown potential is equivalent or superior to present implant materials.

3. The alloy may be susceptible to crevice corrosion in multicomponent implants due to an active value of protection potential.

4. It may be possible to raise the value of the protection potential by reducing the nickel content of the alloy.

5. There appear to be no inherent difficulties in utilizing precipitation hardened alloys for surgical implant applications. 


\section{REFERENCES}

[1] Annual Book of ASTM Standards - Part 46, Specifications F138, F75, F90, F67, F36 (1976).

[2] Cahoon, J.R. and Paxton, H.W., J. Biomed. Res., 2, pp. 1-22 (1968).

[3] Weinstein, A., Amstutz, H., Pavon, G. and Franceschini, V., Materials and Design Considerations for the Attachment of Prostheses to the Musculo-Skeletal System, Biomedical Materials Symposium \#4, Interscience Publication, pp. 297-325 (1973).

[4] Colange10, V.J. and Greene, W.D., J. Biomed. Mat. Res., 3 , 246 (1969).

[5] Bandy, R. and Cahoon, J.R., Corrosion, 33, pp. 204-208 (1977).

[6] Semlitsch, Engineering in Medicine, 3 , \#4, pp. 10-19 (1974).

[7] Smethurst, Edward, University of Nottingham, Nottingham, England. Unpublished data.

[8] Chaturvedi, M.C., Lloyd, D.J. and Chung, D.W., Met. Sc., 10, pp. 373-378 (1976).

[9] Annual Book of ASTM STANDARDS: American Society for Testing and Materials, Specification G5-1972, Part 10, pp. 592-602 (1976).

[10] Cahoon, J.R., Bandyopadhya, R. and Tennese, Laura, J. Biomed. Mater. Res., Vol. 9, pp. 259-264 (1975).

[11] Guyton, Arthur C., Textbook of Medical Physiology, 4th Edition, W. B. Saunders and Co., p. 39 (1971).

[12] Fontana, M.G. and Greene, N.D., Corrosion Engineering, McGraw-Hill, New York, pp. 342-345 (1967).

[13] Holte, R.N., M.Sc. Thesis, University of Manitoba (1976).

[14] Grover, H.J., J. of Mat., Vol. 1, pp. 413-424 (1966).

[15] Wilde, R.E., Corrosion, Vol. 28, pp. 283-291 (1972).

[16] Wilde, R.E. and Williams, E., J. Electrochem. Soc., Vol. 118, pp. 1057-1062 (1971).

[17] Cahoon, J.R. and Paxton, H.W., J. Biomed. Mat. Res., 4, pp. 223-244 (1970).

[18] Cahoon, J.R. and Tennese, W.W., Med. Dev. Art. Org., 1, \#4, pp. 635-645 (1973). 
[19] Semlitsch, M., Eng. in Medicine, 3, \#4, pp. $10-19$ (1974).

[20] McCarrol1, H.R. (M.D.), Trials and tribulations in attempted femoral lengthening", Journal of Bones and Joints Surgery, Vol. 32-A* No. 1, pp. 132-140 (Jan. 1950).

[21] Cleveland, M. (M.D.), Bosworth, D.M. (M.D.) and Della Pietra, A. (M.D.), Subtrochanteric osteotomy and spline fixation for certain disabilities of the hip joint - A preliminary report, J. of B. \& J. Surgery, Vol. 33-A, No. 2, pp. 351-361 and 395-420 (April 1951).

[22] McBride, E.D. (M.D.), A femoral-head prosthesis for the hip joint four years experience and the results, J. of B. \& J. Surgery, Vol. 34-A, No. 4, pp. 989-996 (October 1952).

[23] Laing, P.G. (M.D.), The significance of metallic transfer in the corrosion of orthopaedic screws, J. of B. \& J. Surgery, Vol. 40-A, No. 4, pp. 853-869 (July 1958).

[24] Cohen, J. (M.D.) and Hammond, G. (M.D.), Corrosion in a device for fracture fixation, J. of B. \& J. Surgery, Vol. 41-A, No.3, pp. 524-534 (April 1959).

[25] Laing, P.G. (M.D.), Madaney, L.R. and Grebner, M.A., A radioisotopic investigation of the contanination of screws and tissues by screwdrivers - A study in applied metallurgy, J. of B. \& J. Surgery, Vol. 41-A, No. 3, pp. 535-545 (April 1959).

[26] Ferguson, A.B. Jr. (M.D.), Laing, P.G.(M.D., F.R.C.S.) and Hodge, E.S. (Ph.D.), The ionization of metal implants in living tissues, J. of B. \& J. Surgery, Vol. 42-A, No. 1, pp. 77-90 (January 1960).

[27] Cohen, J. (M.D.) and Foultz, W. Sanford (M.D.), Failure by corrosion of a Steinmann pin used for intramedullary fixation, J. of B.\&.J. Surgery, Vol. 42-A, No. 7, pp. 1201-1206 (October 1960)

[28] Hicks, J. and Cater, W.H., Minor reactions due to modern metal, J. of B. \& J. Surgery, Vol. 44-B** No. 1, pp. 122-128 (February 1962).

[29] Cohen, J. (M.D.), Corrosion testing of orthopaedic implants, J. of B. \& J. Surgery, Vol. 44-A, No. 2, pp. 307-316 (March 1962).

[30] Ferguson, A.B. (M.D.), Akahoshi, Y. (M.D.), Laing, P.G. (M.B.,B.S.) and Hodge, E.S. (Ph.D.), Characteristics of trace ions released from embedded metal implants in the rabbit, J. of B. \& J. Surgery, Vol. 44-A, No. 2, pp. 323-336 (March 1962). 
[31] Charnley, J., The bonding of prostheses to bone by cement, J. of B. \& J. Surgery, Vol. 46-B, No. 3; pp. 518-529 (August 1964)

[32] Scales, J.T., The development of British standards for Surgical implants, J. of B. \& J. Surgery, Volume 47-B, No. 1, pp. 111-117 (February 1965).

[33] Burrows, H. Jackson, Pitfalls in major prosthetic replacement of bone, Proceedings and reports of councils and associations, J. of B. \& J. Surgery, Vol. 49-B, No. 2, p. 387 (May 1967).

[34] Heywood-Waddington, M.B., Use of the Austin Moore prosthes is for advanced osteoarthritis of the hip, J. of B. \& J. Surgery, Vo1. 48-B, №. 2, pp. 236-244 (May 1962).

[35] Law, W.A. (0.B.E.,M.D.), Late results in vitallium-mold arthroplasty of the hip, J. of B. \& J. Surgery, Vol. 44-A, No. 8, pp. 1497-1517, (Dec. 1962).

[36] Mears, D.C., Electron-probe microanalysis of tissue and cells from implant areas, J. of B. \& J.: Surgery, Vol. 48-B; No. 3, pp. 567-576 (August 1966).

[37] Ferguson, A.B. Jr. (M.D.), Laing, P.G. (M.B.,F.R.C.S.) and Hodge, E.S. (Ph.D.), The ionization of metal implants in living tissues, J. of B. \& J. Surgery, Vol. 42-A, No. 1, pp. 77-90 (January 1960).

[38] Pappas, A.M. (M.D.) and Cohen, J. (M.D.), Toxicity of metal particles in tissue culture - Part I: A new assay method using cell counts in the phase of replication, J. of B. \& J. Surgery, Vol. 50-A, No. 3, pp. 535-546 (Apri1 1968).

[39] Mital, M. (M.D.) and Cohen, J. (M.D.), Toxicity of metal particles in tissue culture - Part II: A new assay method using cell counts in the lag phase, J. of B. \& J. Surgery, Vol. 50-A, No. 3, pp. 547-556 (April 1968)

[40] Girzadas, D.V. (M.D.), Greens, S. (M.D.), Clayton, M.C. (M.D.) and Leidholt, J.D: (M.D.), Performance of a hinged metal knee prosthesis, J. of B. \& J. Surgery, Vol. 50-A, No. 2, pp. 355-364 (March 1968).

[41] Homsy, C.A. (M.D.), Stanley, R.F. (M.D.), Anderson, M.S. (M.D.) and King, J.W. (M.D.), Reduction of tissues and bone adhesion to cobalt alloy fixation appliances - Proceedings of the thirtythird annual meeting of the Western Orthopedic Association, J. of B. \& J. Surgery, Vol. 52-A, No. 6, pp. 1269 (Sept. 1970). 
53.

[42 ] Galante, J.0. (M.D.), Rostoker, W. (M.D.), Lueck, R. (M.D.) and Ray, R.D. (M.D.), Sintered fiber metal composites as a basis for attachment of implant to bone - Proceedings of the thirtyseventh Annual Meeting of the American Academy of Orthopaedic Surgeons, J. of B. \& J. Surgery - Vol. 52-A, No. 4, pp. 814(June 1970).

[43] Fuller, D.J. (M.D.), The Ellis plate operation for Smith's fracture, J. of B. \& J. Surgery, Vol. 55-B, No. 1, pp. 173-178 (Feb. 1973).

[44] Meyers, M.H. (M.D.), Harvey, J.P. Jr. (M.D.) and Moore, T.M. (M.D.), Treatment of displaced subcapital and transcervical fractures of the femoral neck by muscle-pedicle-bone graft and internal fixation, J. of B. \& J. Surgery, Vol. 55-A, No. 1, pp. 257-274 (March 1973).

[45] Salvak, E. (M.D.), Long term results of femoral head replacement, J. of B. \& J. Surgery, Vol. 55-A, No. 3, (Apri1, 1973). 